\title{
EVALUATION OF THE EFFECTS OF THE GRADUATE PRACTICE IN SLOVAKIA: COMPARISON OF RESULTS OF COUNTERFACTUAL METHODS
}

\author{
Švábová, L., Kramárová, K., Ďurica, M.
}

Lucia Švábová / Department of Economics, Faculty of Operation and Economics of Transport and Communications, University of Zilina, Univerzitna 1, 010 26, Žilina, Slovakia. Email: lucia.svabova@fpedas.uniza.sk.

Katarína Kramárová / Department of Economics, Faculty of Operation and Economics of Transport and Communications, University of Zilina, Univerzitna 1, 010 26, Žilina, Slovakia. Email: katarina.kramarova@fpedas.uniza.sk.

Marek Durica / Department of Quantitative Methods and Economic Informatics, Faculty of Operation and Economics of Transport and Communications, University of Zilina, Univerzitna 1, 010 26, Žilina, Slovakia. Email:marek.durica@fpedas.uniza.sk.

\begin{abstract}
Graduate Practice is in Slovakia one of the measures of active labour market policy aimed at decreasing the unemployment rate of young graduates. It is one of the most frequently used interventions by young jobseekers under the age of 26 ; similar measures are used in other European Union (EU) member states. The specific objective of this intervention is to provide young jobseekers to gain the first contact with the labour market, first work experience and work habits that may be attractive to potential employers. The intervention is financed from the European Social Fund (within the Operational Program - Human Resources and the priority axis - Youth Employment Initiative) and the state budget. This fact requires ad 1) to evaluate the eligibility of drawing these resources and ad 2) to evaluate the effectiveness of the use of resources in terms of employability and sustainability of participants of the intervention in the labour market, the second of which is the primary objective of this study. The European Commission has increasingly required the member states of the EU to carry out impact evaluations of funded interventions and to develop evidence-based policies that will implement the results of such evaluations. The aim of this study is, therefore, to evaluate and review the effects of the Graduate Practice on the employability of young jobseekers in conditions of Slovakia. This evaluation is carried out using a counterfactual approach by comparing the results of treated and non-treated individuals by applying the three most used methods: regression adjustment, instrumental variable, and propensity score matching method. The results indicate significant effects of the Graduate Practice on the employability of young jobseekers and their sustainability in employment. The results of the evaluation are valuable mainly for policymakers, i.e. in setting the rules of the intervention and its eligibility to make the measure more effective or potentially in preparing other measures aimed at youth unemployment.
\end{abstract}

Implications for Central European audience: The findings of the evaluation may inspire policymakers in other countries than Slovakia to introduce similar or new programs for the 
youth unemployed. The results of this study may also be used for an international comparison of the effectiveness of interventions if a similar program for youth unemployed operates in another country, which may be appropriate mainly from the point of view of being a program(s) co-financed by the European Social Fund.

Keywords: counterfactual evaluation; Graduate practice; active labour market policy; intervention

JEL Classification: C54, J08, J64

\section{Introduction}

Youth unemployment has an impact on both today and future economies, causing economic deprivation and affects the social status and psyche of young individuals. In essence, it is a multidimensional phenomenon faced not only by the developing but also by the developed economies of the world. Despite the culmination of the problem of youth unemployment at the beginning of the second decade of the 21 st century, problems with youth employment began to be discussed in Western Europe as early as the early 1980s, when large numbers of young people began to enter the labour market. Even then, economists pointed out that the advantage of young people at work is their enthusiasm for the application of education (qualifications), fresh ideas, and motivation to assert themselves. On the other hand, they are disadvantaged by the lack of work and professional experience and by the interest in experimenting with a career, which can lead to low loyalty to the employer (Cefalo et al., 2020).

As reported by Potluka et al. (2016), employment is one of the main policy objectives of the EU. To alleviate the problems of unemployment (not only) of young people, labour market policy instruments (measures) have been introduced in Slovakia, but also in other countries, the main task of which is to reduce unemployment and increase employment. Implementation of a counterfactual impact evaluation of the EU Cohesion Policy allows examining how one of the most important EU policies works. These studies focus on the assessment of national policies and apply quantitative econometric methods to evaluate the impact of the EU Cohesion Policy interventions in the field of employment (Potluka et al., 2016). The idea of evaluation of intervention programs firstly appeared formally in the EU Fund Regulations in 1988. Since then, evaluation requirements have evolved in scope and sophistication to include evaluation at political, program and project levels (Gripaios et al., 2008).

In recent years, the Directorate-General for Employment, Social Affairs and Inclusion (DG EMPL) has launched several initiatives to support the submission of impact assessments of the European Social Fund interventions (Elia et al., 2016). This is probably the reason why the European Commission is also putting pressure on applying evaluation methods to empirically test the impact of the EU cohesion policy (Potluka et al., 2016). Impact assessments are mandatory for the EU member states, as they are listed in the Regulation (EU, Euratom) 2018/1046 of the European Parliament and the Council on the financial rules applicable to the general budget of the Union and in the Regulation No. 1303/2013 (EU) of the European Parliament and the Council laying down common provisions on the European Regional Development Fund, the European Social Fund, the Cohesion Fund, the European 
Agricultural Fund for Rural Development and the European Maritime and Fisheries Fund and laying down general provisions on the European Regional Development Fund, the European Social Fund, the Cohesion Fund and the European Maritime and Fisheries Fund. The EU is nowadays increasingly encouraging the member states to implement evidence-based policymaking models (Knox et al., 2018). These models use the results of rigorous evaluations of the impacts of the programs in deciding whether to finance, terminate or improve programs. Rigorous empirical studies assure policymakers that social programs help to improve the situation of citizens while at the same time giving them some evidence that intervention programs are responsible for this improvement. In recent years, the first successes in some EU countries have led to efforts to demand the presentation and use of evidence-based policy and budget setting, as well as efforts to develop new laws concerning the results of the effects of policies (Knox et al., 2018). The budgetary problems of the member states and the consequent efforts to save funds also increase the pressure to know how effectively these funds are spent (Koszela, 2020; Mikiashvili \& Lobzhanidze, 2017). In this context, the question of what the real impacts of policies are arises (Pelucha et al., 2019; Potluka et al., 2016). There is a growing political interest in demonstrating the impact of intervention programs. The question is not only what was achieved by using the funds but also whether their use caused a significant difference or what would have been achieved if they had not been used (Elia et al., 2016).

In this study, we focus on assessing the impact of the intervention program "Financial Contribution for Implementation Graduate Practice" (hereinafter Graduate Practice), which is set to the conditions of the Slovak labour market for youth unemployed under the age of 26 . The main contribution of this study is the evaluation of the impact of the Graduate Practice on the employability of its beneficiaries using the triangulation of the methods, namely the regression adjustment method, the propensity score matching method and the instrumental variable method using data that are as current as possible, which we were able to obtain from Slovak institutions. At the same time, the triangulation of methods provides the possibility of comparing the results and strengthening the conclusions obtained from the evaluation. In the field of application of counterfactual methods, there is a big gap in Slovakia and great potential for evaluating the effects of programs. The results of these evaluations are very important for future policy-making of these programs for the unemployed. This also applies to a large extent to the evaluated program Graduate Practice, which is aimed at the young unemployed, who are an important component of the potential working population.

The rest of this article is organised as follows. The literature review focuses on the issue of young unemployed and also mentions the area of evaluation of programs for them in the EU Member States. The third chapter briefly introduces the main principles of the intervention program Graduate Practice, presents the theoretical background of the counterfactual evaluation and the methods applied in the study. Except that, we provide necessary information on the used data. The fourth chapter presents the results of evaluations carried out by three different methods in the form of quantification of the impact of the intervention on the employability of the beneficiaries of the program intervention. We also discuss the strengths and weaknesses of the realised evaluations and outline the possibility of the further direction of the analysis. The conclusion provides a brief overview of the study conducted in this article and the results of the evaluation of the intervention. 


\section{Literature Review}

The general definition explains unemployment as the situation when part of the workforce does not participate in the work process. Then, an unemployed person is someone of the "working age" who does not participate in the work process but is willing and able to work and is actively searching for a job. Following these definitions, a young unemployed is a person who meets these preconditions and at the same time is under the age of 29 (usually). The maximum age limit may vary from country to country, depending on school education systems and the expected decisive age of the finished transition to the labour market (school-to-worktransition). According to the OECD, a young unemployed is a person who is $15-24$ years old and who officially reports that he/she is without work but is available for work and that has taken active steps to find work in the last four weeks (OECD, 2020a).

Currently, the youth unemployment rate among the OECD countries reached $16.7 \%$, among the EU countries is by 0.1 percentage point higher (situation in June 2020). The most noticeable situations are even in the developed countries such as the USA (20.7\%, compared to June $2019-8.1 \%)$, Luxemburg $(26.7 \%$, compared to June $2019-17.5 \%)$, Canada (27.5\%, compared to June $2019-11 \%)$, and Sweden $(28.7 \%$, compared to June 2019 $18.4 \%)$. The highest youth unemployment rate was recorded in Spain (40.8\%, compared to June $2019-32.7 \%$ ), more than twice than is the average in the OECD countries. A relatively low rate - below $10 \%$ - has long been reported in countries (although there has been an increase as well) such as Japan, Germany, Czech Republic, Israel, and Poland (OECD, 2020b).

From a macroeconomic point of view, the greatest risk is the transformation of this group of unemployed into the long-term unemployed with an impact on the economic growth, country's social and pension system, and budget revenues (Gregova \& Dengov, 2015; Stefanik et al., 2014a). From the view of employers (microeconomic point of view), employers commonly face higher costs of investment when employing young jobseekers; on the other side face lower termination costs, which may make the situation on the youth labour market more sensitive to demand-side fluctuations (Bell \& Blanchflower, 2011; Caliendo \& Schmidl, 2016). From the view of young jobseekers, as a rule, they are more often unemployed compared to other age groups. They are more often employed in precarious or temporary jobs, in jobs within the secondary labour market with lower wages and lower social security rates (Kostolna, 2010; OECD, 2010; Quintini et al., 2007). In addition, at a time of economic crisis (which is also reflected today in response to the Covide-19 pandemic), the displacement of young people from the labour market, including school leavers who, under standard conditions, would have no problem with their integration into the labour market; their transformation into "hard-to-integrate new entrants" is almost the rule (European Parliament, 2020; Kostolna, 2010).

In the case of Slovakia, youth unemployment is frictional, occurs mainly in cycles that are in close connection with the termination of the relevant level of education (the cycle usually starts in June and ends in the following year in May). Currently, the Slovak youth unemployment rate is at the level of $18.1 \%$, i.e. by 1.7 percentage points higher compared to the situation one year ago (situation in June 2020) (OECD, 2020b). Except for the territorial disproportion in youth unemployment (it copies the development of unemployment and the formation of job opportunities in individual regions), a specific feature of the Slovak labour 
market is the fact that a significant part of graduates does not work in the field they studied if they work at all. This structural mismatch of qualification requirements on the demand side and the qualification on the supply side has been deepening since the establishment of independent Slovakia. This fact is followed by the issue of low competitiveness of graduates in the labour market compared to job seekers who have already worked since it is assumed that they have established work habits and experience (Barcakova \& Janas, 2019; Golias, 2014; Grandtnerova, 2014; KPMG, 2015a; Stefanik et al., 2014b).

Insufficient work experience and degree of connection of studies with the requirements of practice (employers) have been confirmed as one of the main causes of the barrier to youth employment in other countries as well, e.g. in Czechia (e.g. Janicko, 2012; Research Institute of Labor and Social Affairs of the Czech Republic, 2003), in Poland (e.g. Dunsch, 2016; Maguire et al., 2013; Polakowski, 2012), in Romania (e.g. Marginean, 2014; Patache, 2015), in Hungary (Agocs \& Agocs, 1994; Noelke \& Horn, 2014; Walther et al., 2008), etc. In the case of Slovakia, the unemployment of young people, including their preparation for the labour market, is also a problem in marginalised groups, especially with regard to the Roma community.

Several studies in connection with youth unemployment also point to the phenomena of young people, who are neither in employment nor in education or training - so-called NEET. The acronym NEET refers to youths with ages between 15 and 29 years who, irrespective of their level of studies, are not employed and do not follow any educational programme, hence being exposed to higher risks of social and labour market exclusion. (Balan, 2015) According to Eurostat (2020), in the $4^{\text {th }}$ quarter of 2019, the NEET rate of the $15-24$ yearolds in the EU reached $10 \%$ (including 28 countries). The lowest rate was recorded in the Netherlands (4.2\%); conversely, the worst situation was indicated in Italy (17.9\%). According to gender statistics, it was shown nationwide that more women than men were neither in employment nor in education or training (in the case of a fraction for several age groups as well). This gender difference may be attributed, in part, to family structures, as a higher proportion of young women (than young men) spend time caring for children and/or other family members. Outside the EU, the largest disparities were observed in Turkey. Lelkes et al. (2019) emphasise that the number of inactive young individuals in Slovakia is much higher than the official youth unemployment rate. According to Eurostat (2020), the NEET rate of 15 -24 years old reached $10.8 \%$, in the age group of $15-34$ for $17.2 \%$. In Lelkes et al. (2019), the authors state that up to $80 \%$ of inactive young people as the reason for their inactivity stated mainly lack of education. Only $2 \%$ of them felt prepared to work. However, they were not looking for a job because they did not believe that some work was "available". They also emphasise the functionality of the institutional provision of assistance to this group of young people. Styczynska (2020) concludes her study and states that training programs are a good starting point to fight the NEET problems since they can increase the young person's chance of finding employment, especially for those who are not seeking employment at the moment (but not only).

Several authors in other countries have also studied the impact of support programs for young unemployed people on their employment. For example, the studies of Ragazzi (2014), Cappellini et al. (2019) and Donato et al. (2018) are focused on young people in Italy. The authors evaluated the effects of training programs for young unemployed people and other disadvantaged groups of jobseekers in Italy. Several studies focused on the evaluation of 
training programs were also published in Germany (e.g. Caliendo \& Schmidl (2016); Mueller \& Gaus, (2015)), Romania (Popescu \& Roman, 2018), Czech Republic (e.g. Dvoulety (2017); Dvoulety \& Lukes (2016); Pelucha et al., (2019)).

In Slovakia, only a few evaluations of intervention programs aimed at the labour market were realised so far to evaluate the effects of interventions for the jobseekers, e.g. Barosova \& Keselova, (2012); Borik \& Caban (2013b); Burda \& Lubyova (1995); Harvan (2011b); Karasova (2013); Kurekova Mytna et al. (2013); Lubyova (1997); Stefanik (2014); Stefanik et al. (2014b, 2020). Some of them are, among others, aimed also at the evaluation of the Graduate Practice. However, the studies mostly analysed data from older periods, and few of them use the counterfactual approach of evaluation. Table 1 shows a comparison of already published evaluation studies of Slovak authors, together with the study presented in this article in terms of the evaluated interventions and the type of data used in the studies.

Table 1 | Evaluation studies of Slovak authors

\begin{tabular}{ccc}
\hline Authors & $\begin{array}{c}\text { Evaluated } \\
\text { interventions }\end{array}$ & Data used \\
\hline Harvan (2011) & $\begin{array}{c}\text { two ALMP interventions, } \\
\text { including Graduate } \\
\text { practice }\end{array}$ & aggregated half-yearly data \\
\hline
\end{tabular}

$\begin{array}{cc}\begin{array}{c}\text { Barosova \& Keselova } \\ (2012)\end{array} & \begin{array}{c}\text { ALMP interventions, } \\ \text { including Graduate } \\ \text { practice }\end{array}\end{array} \begin{gathered}\text { data on the total number of participants and } \\ \text { expenditures on the instrument, questionnaire }\end{gathered}$

\begin{tabular}{|c|c|c|}
\hline Borik \& Caban & $\begin{array}{l}\text { eleven ALMP } \\
\text { interventions, including } \\
\text { Graduate practice }\end{array}$ & $\begin{array}{c}\text { sample of micro-data from the database of the } \\
\text { COLSAF, app. 1,000 participants in individual } \\
\text { measures }\end{array}$ \\
\hline
\end{tabular}
Borik, Durica, two ALMP interventions, Molnarova, \&
Svabova (2015) including Graduate practice
micro-data from the database of the COLSAF and SIA

\section{Svabova, Kramarova, \\ Durica (2020) - $\quad$ Graduate practice \\ micro-data from the database of the COLSAF current study and SIA}

Source: own elaboration

Overall, we can say that despite the EU requirements and efforts, we have to say that the numbers of evaluations of program results are still insufficient. However, implementation of evidence-based policy-making is impossible without rigorous evaluation results. 


\section{Methodology and data}

\subsection{Basic principles of the Graduate practice intervention}

The labour market policy in Slovakia is defined by the Act on Employment Services no. $5 / 2004$ Coll. Instruments of labour market policy (LMP) are in Slovakia, as well as across the $\mathrm{EU}$, categorised into three basic groups to increase their comparability: LMP services (category 1); LMP measures (categories 2 to 7) and LMP support (categories 8 and 9) (Stefanik, 2014). Intervention Graduate practice belongs to the LMP measures category and is defined in $\S 51$ of the Act on Employment Services. The aim of introducing this intervention was to enable young graduates to get the first contact with the labour market and with potential employers to acquire first work skills and habits. The graduate practice is performed by a young jobseeker under the age of 26 years at a selected employer who provides it, where the graduate is doing the work assigned to him by the employer. The Graduate practice is officially implemented through local labour offices in Slovakia, where both the employer and the graduate sign a contract with the Labour, Social Affairs and Family Office on the implementation of this intervention. Participation in the Graduate practice should have for the intervened individuals an effect in the form of gaining employment during the impact period after the intervention. From a macroeconomic perspective, the effects of intervention should lead to a reduction in the unemployment rate of young people under the age of 26 and a reduction in state budget expenditure on their unemployment.

The duration of the Graduate practice is at least three months and at most six months. According to the current wording of the Act, there is no possibility of its extension and repetition. The graduate works with the employer for a maximum of 20 hours per week. During the Graduate practice, the relevant Labour, Social Affairs, and Family Office pay a monthly flat-rate allowance of $65 \%$ of the minimum subsistence amount to the graduate who undertakes the Graduate practice with the employer. In 2019 and 2020 (until 30th June 2020), this amount is EUR 136.63 monthly. In 2018 it was EUR 133.30, and in 2017 it was EUR 129.66. Figure 1 shows the expenditure for the implementation of this intervention over the years 2004 to 2018 (bar chart), together with the number of treated persons who participated in the Graduate practice during these years (line chart).

Since the introduction of this intervention in 2004, the Act has undergone several changes. The main conditions of eligibility of the applicant changed (age of the applicant, the minimum period of registration in the database of jobseekers) as well as the duration of the intervention and the possibility of its repetition. However, during the period under the evaluation in this study, the conditions were the same for each beneficiary.

Participation in the Graduate Practice is voluntary in Slovakia: every eligible jobseeker who applies for the intervention will receive the treatment. There is no further selection of the candidates. 
Figure 1 | Number of participants in the Graduate practice and total expenditure on its implementation

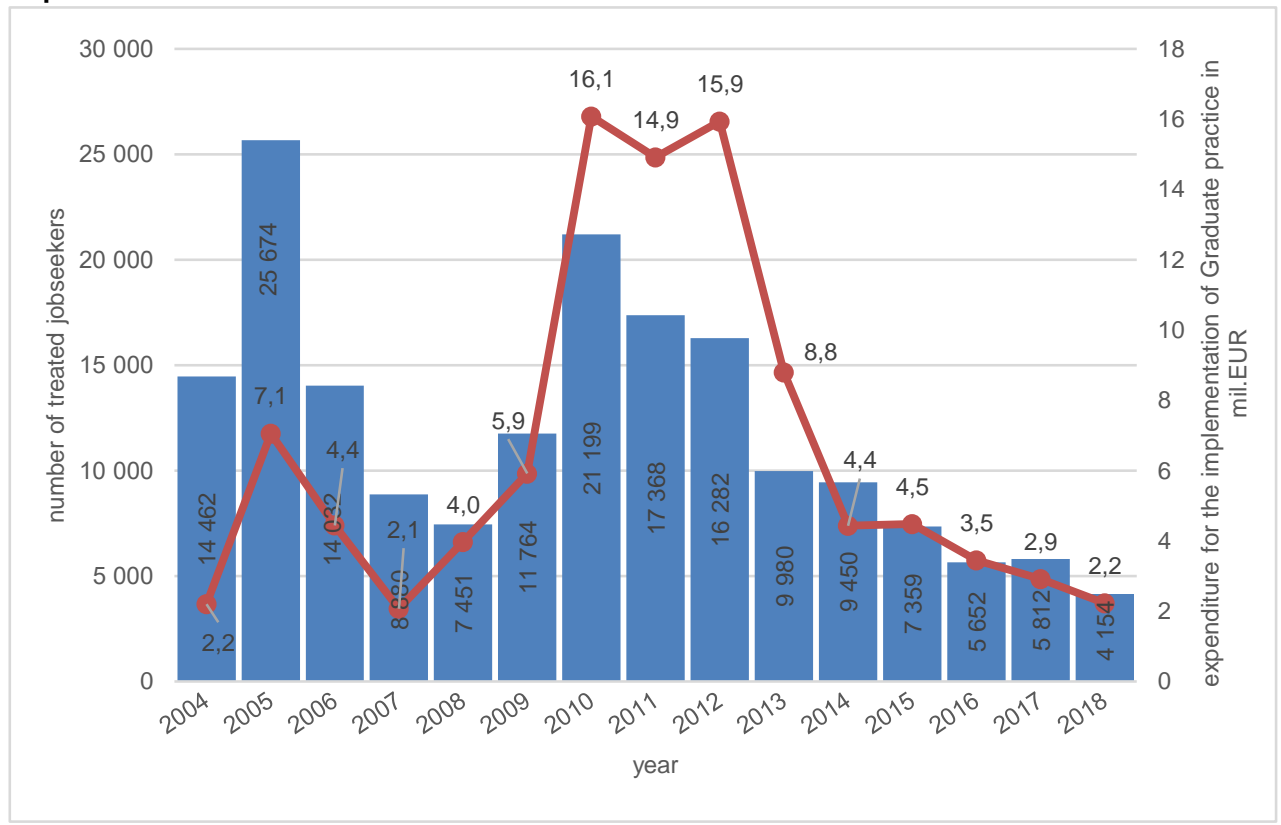

Source: own data processing from Eurostat

From the point of view of companies, it is advantageous to provide the Graduate Practice for youth unemployed, because the young graduate in the company performs work (maximum 20 hours per week) assigned to him by the employer, but the employer does not have to pay him a wage for this work, as it is paid in the form of an intervention allowance from the Labour Office. At the same time, in this way, companies gain contact with young graduates who (if they prove themselves at work) can be potential employees. The company thus does not run the risk of hiring a full-time employee but verifies the working ability and working potential of the young employee in the form of this practice.

The program, which has been running in Slovakia since 2013 as a part of the "Youth Employment Initiative" thanks to financial support from the European Social Fund under the Operational Program "Human Resources 2014-2020", is also focused on companies. Through this program, apprenticeships, graduate practice, job opportunities and various forms of further education are provided to unemployed young people. In Slovakia, several programs to support employment and further education of young people have taken place and are still being implemented within the framework of this initiative. One of them is the program "Graduate Practice starts employment", which has been running since 2015. Activity 2 of this program is aimed at employers who allow young graduates to participate in the Graduate Practice or create a new full-time job for them after completing this practice. In this program, the financial contribution is provided to the company in the form of an advance on compulsory insurance premiums, which an employer has to pay monthly for his employee. The maximum monthly allowance per employer in 2020 is 294.96 Eur. This program aims to further support employers who are willing to enable young people to gain work experience in their company. 


\subsection{Data}

The first very important aspect of quality evaluation of interventions is the existence and availability of quality data (Gripaios et al., 2008). In this study, we use data on registered unemployed jobseekers from the database of the Central Office of Labour, Social Affairs and Family of the Slovak Republic. To evaluate the effects of the policy, we use the results of the work experience of the individuals monitored during the 2-years impact period after the intervention, coming from the Social Insurance Agency of the Slovak Republic.

A total of 96,860 young jobseekers were enrolled in the study, of which 83,907 were nontreated individuals, and 12,953 individuals were treated by the Graduate practice. About them, we have individual data on in total 32 variables, including the variables serving for control of eligibility of participants or logical controls of the values (for example date of start of the intervention, date of the end of intervention - these were used to calculate the variable duration of the intervention to control its length according to the Law). For the evaluation, thus for the creation of the models, the following variables (Table 2) were used.

Table 2 | Variables used in the evaluation

\begin{tabular}{|c|c|c|}
\hline Variable name & Description & Values \\
\hline$I D$ & $\begin{array}{l}\text { anonymised individual's } \\
\text { identification code }\end{array}$ & numerical code \\
\hline intervention & $\begin{array}{l}\text { participation in the Graduate } \\
\text { practice }\end{array}$ & $\begin{array}{c}0=\text { non-treated } \\
1=\text { treated }\end{array}$ \\
\hline total evidence & $\begin{array}{l}\text { all previous registrations in the } \\
\text { Database of jobseekers }\end{array}$ & days \\
\hline last evidence & $\begin{array}{l}\text { last evidence in the Database of } \\
\text { jobseekers }\end{array}$ & days \\
\hline age at registration & $\begin{array}{l}\text { age at the time of the registration in } \\
\text { the database of jobseekers }\end{array}$ & years \\
\hline age & $\begin{array}{l}\text { age at the beginning of the } \\
\text { intervention }\end{array}$ & $\min 26$ years \\
\hline gender & gender & $\begin{array}{l}\text { male/female, plus the category } \\
\text { "unspecified" }\end{array}$ \\
\hline marital status & $\begin{array}{l}\text { marital status at this particular entry } \\
\text { in the database of jobseekers }\end{array}$ & $\begin{array}{c}\text { single / married / divorced / } \\
\text { widow(er) , plus the category } \\
\text { "unspecified" }\end{array}$ \\
\hline level of education & $\begin{array}{l}\text { degree of the highest education at } \\
\text { the time of the entry into the } \\
\text { Database of jobseekers }\end{array}$ & $\begin{array}{l}\text { based on the international } \\
\text { classification of degrees of } \\
\text { education, plus the category } \\
\text { "unspecified" }\end{array}$ \\
\hline $\begin{array}{l}\text { region of } \\
\text { permanent } \\
\text { residence }\end{array}$ & $\begin{array}{c}\text { region of permanent residence at } \\
\text { the time of the entry in the Database } \\
\text { of jobseekers }\end{array}$ & $\begin{array}{l}8 \text { regions of Slovakia, plus the } \\
\text { category "unspecified" }\end{array}$ \\
\hline disadvantage & $\begin{array}{c}\text { disadvantage under Act no. 5/2004 } \\
\text { on employment services, } \S 8 \\
\text { Disadvantaged jobseeker }\end{array}$ & $\begin{array}{l}\text { no disadvantage / school-leaver / } \\
\text { long term unemployed / low } \\
\text { education / no regularly paid job / } \\
\text { care / person with disability }\end{array}$ \\
\hline school & $\begin{array}{l}\text { type of last (attended) school at the } \\
\text { time of the entry into the Database } \\
\text { of jobseekers }\end{array}$ & $\begin{array}{l}41 \text { different types of schools, plus } \\
\text { the category "unspecified" }\end{array}$ \\
\hline
\end{tabular}




\begin{tabular}{|c|c|c|}
\hline $\begin{array}{l}\text { driving license } \\
\text { group } 1\end{array}$ & $\begin{array}{l}\text { ownership of the driving licence of } \\
\text { the motorcycle category: AM, A1 } \\
\text { and A }\end{array}$ & $\begin{array}{c}0=\text { not owner of the licence; } \\
1=\text { owner of the licence }\end{array}$ \\
\hline $\begin{array}{l}\text { driving license } \\
\text { group } 2\end{array}$ & $\begin{array}{l}\text { ownership of the driving license of } \\
\text { the cars and small lorries category: } \\
\text { B1, B and B }+E\end{array}$ & $\begin{array}{c}0=\text { not owner of the licence; } \\
1=\text { owner of the licence }\end{array}$ \\
\hline $\begin{array}{l}\text { driving license } \\
\text { group } 3\end{array}$ & $\begin{array}{l}\text { ownership of the driving licence of } \\
\text { the truck category: } \mathrm{C} 1, \mathrm{C} 1+\mathrm{E}, \mathrm{C} \\
\text { and } \mathrm{C}+\mathrm{E}\end{array}$ & $\begin{array}{c}0=\text { not owner of the licence; } \\
1=\text { owner of the licence }\end{array}$ \\
\hline $\begin{array}{l}\text { driving license } \\
\text { group } 4\end{array}$ & $\begin{array}{l}\text { ownership of the driving licence of } \\
\text { the large lorries and buses: } D 1, D 1 \\
+E, D \text { and } D+E\end{array}$ & $\begin{array}{c}0=\text { not owner of the licence; } \\
1=\text { owner of the licence }\end{array}$ \\
\hline $\begin{array}{l}\text { driving license } \\
\quad \text { group } 5\end{array}$ & $\begin{array}{c}\text { ownership of the driving licence of } \\
\text { the tractor category: } T\end{array}$ & $\begin{array}{c}0=\text { not owner of the licence; } \\
1=\text { owner of the licence }\end{array}$ \\
\hline
\end{tabular}

Source: own elaboration

Moreover, to create the model of logistic regression for the propensity score, also the following variables characterising the environment in which an individual lives and seeks work were included: the ratio of women in the district, district size, district population density, number of municipalities in the district, number of towns in the district, unemployment rate. All qualitative variables were used as dummy variables, including all possible reasonable values in the regression models. The SPSS software in which we worked automatically excludes one variable as a reference category and no regression coefficient is estimated for this variable, so these reference categories are not included in the model (see tables of the models in Appendix).

The characteristics of the variables are described in more detail in the study of Svabova \& Durica (2018). Preparation of the database of jobseekers was undoubtedly the most difficult step of the evaluation, where it was necessary to prepare the data and perform all controls of variables: logical checks (for example, the sequence of dates, dates belonging to the evaluated period, non-contradiction values of the variables such as the level of education and the type of school etc.) controls on the eligibility of the participant (age, minimum registration period, etc.). We evaluated only the completed intervention program, so checking the duration of the intervention was one of the logical checks in the preparation of the database. If the condition of the duration of the intervention (from 3 to 6 months) was not met, the individual was excluded from the database, as it could be either an error in the records, or an illegal duration of support, or unfinished intervention (the candidate found a job or left abroad, the applicant's death, lack of interest in completing the intervention and other reasons). It then makes no sense to evaluate the unfinished intervention in terms of its impact on employment.

In addition to the initial pre-intervention characteristics of individuals, we have values of result variables used to estimate the effects of the intervention. In this study, the most important result variable is the variable placed in the labour market, which measures the length (number of days) of employment in the form of individual self-employment or the form of full-time work. The differences in the mean values of this variable over the impact period in the group of treated and non-treated individuals reflect the net effect of the intervention. 


\subsection{Brief methodology of counterfactual impact evaluation}

Impact evaluations, as understood in this study, usually refer to a policy that has already been implemented (Trivellato, 2011). It is, therefore, a retrospective (ex-post) evaluation based on monitored data to compare the expected impact of the intervention with its actual results as well as to evaluate the long-term impact of the program (Gripaios et al., 2008). The study uses quasi-experimental impact evaluation approaches that compare the results of program participants with those of a group of people who are very similar to them but who were not participants in the program.

As reported by Arco-Tirado et al. (2018) and Lenihan \& Hart (2016), the quasi-experimental evaluation approaches aim to build the comparison group of those individuals who did not participate in the program and, therefore, their results in the reporting impact period are not affected by the intervention. This group should be as similar as possible to the treated group in terms of their basic (pre-intervention) characteristics. Subsequently, by comparing the values of the result variables of this group with the results of the treated group, it is possible to quantify the effects of the intervention (Arco-Tirado et al., 2018). The creation of a control group is essential for carrying out the evaluation for the following reason. As reported by Frondel \& Schmidt (2005), at the same time, it is not possible to observe the results of an individual participating in the intervention and the potential results of the same individual if (s)he was not the participant of the intervention. Everyone can either participate in the program or not. Thus, only one of the two result variables can be observed in every individual. The control group, therefore, serves to estimate what the individual's results would have been in the program or policy had not been implemented, thus creating a so-called counterfactual situation (White \& Sabarwal, 2014). In literature, this situation is most often described by the words "what would have happened in the absence of intervention". These types of impact evaluation of intervention policies are called counterfactual impact evaluations (CIE).

In this study, we focus on comparing the results of the Graduate practice evaluation, obtained using three selected methods that, according to the author, belongs to the group of the most commonly used methods in this field:

1. the regression adjustment method,

2. the instrumental variable method,

3. the propensity score matching method (Cerulli, 2015).

The first mentioned method, the regression adjustment method, is based on the creation of a linear regression model of the dependence of result variable on the pre-intervention observable characteristics of an individual and a variable expressing participation in the intervention (in the form of a dummy variable with the values 0 for non-participants and 1 for treated participants). The effect of the program on the result variable is then quantified by the estimated regression coefficient of this variable, detecting participation in the intervention. In this study, we create a regression model for the result variable placed in the labour market based on all pre-intervention characteristics of individuals (variables listed in Table 1, qualitative variables are used in the form of a set of dummy variables), together with the variable treated, which expresses participation / non-participation of the individual in the intervention. The evaluation of the effects of the program obtained through the regression adjustment method is generally considered to be biased since this method does not take into 
account the problem of self-selection of participants in the intervention and the impact of unobservable factors (such as individual motivation, diligence, talent, etc.) (Angrist \& Pischke, 2009). In this study, this method of evaluation is used to compare the results with other methods and to reinforcing the results of the effects of the intervention.

The second method used in the study is the instrumental variable method, which tries to incorporate the influence of non-measurable factors to the evaluation, which may have a significant impact on the individual's performance. These are the aforementioned characteristics, such as motivation, diligence, purposefulness, etc. Their effect can both increase the probability of an individual's participating in an intervention but also affect the values of result variables. The instrumental variables method is used to alleviate this problem of the existence of non-measurable factors and the self-selection of participants in the intervention (Caliendo et al., 2017; Caliendo \& Schmidl, 2016). A suitable instrumental variable is such a variable that affects an individual's participation in an intervention but does not affect his /her results during the impact period after the intervention. Based on several studies (e.g. CRIE (2014)), we used the distance of the permanent residence of the jobseeker from the local labour office as this instrumental variable. It is assumed that this affects participation in the intervention but does not affect the individual's performance after the program ends.

The last method used in this study is the propensity score matching method. We consider it the most frequently used method for evaluating the impact of programs currently. Two previous methods work with samples of eligible treated participants and those control individuals who were also eligible but not interested (or not selected) to participate but do not work with the matching of the samples. To achieve more accurate results, however, matching of individuals from the treated and control groups is usually used. Matching aims to find for each treated participant a control individual that is as similar as possible. This matching of individuals will create the most accurate counterfactual situation for every individual, and the results obtained from the evaluation based on matched samples will be more accurate and reliable. This matching is in the propensity score matching method performed using the estimated value of the probability of the individual's participation in the intervention, the socalled propensity score. This score is estimated by constructing a logistic regression model of intervention's participation (dummy variable intervention with values of 0 and 1 ) on all the individual's characteristics and other variables. Then, based on the estimated propensity score values, each intervention participant is matched with the non-treated control individual that has the propensity score as close as possible. This matching could be done by different methods. In this study, we use the calliper matching method, whose aim is to find the nearest neighbour within the specified radius of the possible propensity score values. We used a calliper of 0.00001 , in which a pair is searched for every treated individual. We chose this, as small as possible, the value of the radius to achieve the best possible balance of the matched samples. Matching is done in a 1:1 way, so every treated individual is matched with one nontreated individual (nearest neighbour) within a given radius. Matching could be done with or without the replacement, depending on whether the control individual is used as a suitable match for only one treated individual or several individuals (Caliendo et al., 2017). In this study, we used matching with replacement, so every non-treated individual can serve as a counterfactual to more treated individuals. The advantage of this approach is the independence from the order of matching of individuals. Finally, by comparing the mean 
values of the result variable placed in the labour market in the matched groups of treated and non-treated individuals, we get an estimate of the net effect of the intervention.

\section{Empirical results}

\subsection{Evaluation by regression adjustment method}

As mentioned above, the evaluation of the effects of the intervention Graduate practice by this method is based on the creation of a linear regression model of the dependence of the result variable placed in the labour market on all input variables of the individual and the dummy variable of intervention. As there are 91 variables in the model (including dummy variables for the qualitative variables), Annex A provides the table of the whole model and its estimated coefficients. The estimated coefficient of variable intervention, expressing the net impact of the intervention on the individual's placement in the labour market, as well as the characteristics of this model, are presented in Table 3.

Table 3 | Evaluation by regression model and its characteristics

\begin{tabular}{lcc}
\hline Regression adjustment method & & \\
\hline Characteristic & Value & p-value \\
\hline R & 0.447 & \\
R square & 0.200 & \\
Adjusted R square & 0.199 & \\
ANOVA test of model significance & 284.956 & 0.000 \\
Net effect of the Graduate practice & $\mathbf{7 7 . 7 8 0}$ & $\mathbf{0 . 0 0 0}$ \\
\hline
\end{tabular}

Source: own elaboration

The coefficient for the variable intervention in the regression model for the result variable placed in the labour market is 77.78 . This means that on average, non-treated individuals who did not participate in the Graduate practice were employed (in the form of self-employed or full-time employment) almost 78 days shorter than treated graduates in the reporting period (24 months). The $p$-value of the significance test of the regression coefficient $(\mathrm{sig}=0.000)$ also shows that the intervention variable is statistically significant in the given regression model for the dependent variable placed in the labour market.

The evaluation of the effects of the Graduate practice on the employment of young jobseekers by this method thus showed a significant positive impact of the program. However, as mentioned above, this method is more commonly used to compare results with other methods because it is considered to be inaccurate, and the results of evaluating the effects of interventions obtained with it are usually overestimated.

\subsection{Evaluation by the instrumental variable method}

In the case of the intervention Graduate practice, we are facing the problem of the selfselection of participants in the intervention. As we mentioned, in Slovakia, this intervention is for eligible jobseekers voluntary. In addition to the values of input variables (characteristics of the individuals), immeasurable factors have a very strong impact on their voluntary participation in the intervention. The effects of these factors can both increase the probability of an individual's participating in the intervention but also affect the values of result variables. The instrumental variables method seeks to reduce the impact of the self-selection effect and selection bias effect on evaluation results. As recommended by Cerulli (2015), the 
instrumental variable method (with the variable distance of the permanent residence as an instrument) is applied using the three-stage least squares method. We list the table of the resulting model from the third step of this procedure in Annex $B$. The net effect of the intervention is quantified by the estimated coefficient of variable step2 in this table. Table 4 shows the characteristics of this regression model, together with the estimated coefficient of the effect of the intervention on the employment of individuals and its significance test.

For the result variable placed in the labour market, the effect of the intervention was estimated to be 138.74 days. That means the treated individuals stay in employment for an average of almost 139 days (4.6 months) longer than non-treated. This effect of the Graduate Practice is also statistically significant in the model $(\mathrm{sig}=0.000)$.

Table 4 | Evaluation by the method of instrumental variable and its characteristics

\begin{tabular}{lcc}
\hline Instrumental variable method & & \\
\hline Characteristic & Value & p-value \\
\hline R & 0.440 & \\
R square & 0.194 & \\
Adjusted R square & 0.193 & \\
ANOVA test of model significance & 283.986 & 0.000 \\
Net effect of the Graduate practice & $\mathbf{1 3 8 . 7 4 0}$ & $\mathbf{0 . 0 0 0}$ \\
\hline Source: own elaboration & &
\end{tabular}

\subsection{Evaluation by propensity score matching method}

The third method of evaluation will be based on the matching of propensity score values of the treated and non-treated individuals. We created a logit model for estimating the probability - propensity score of intervention participation for each treated and non-treated individual (Annex C). According to Cerulli (2015), we used the minimum and maximum values of the propensity score to define the common support area, which in this case is in the interval (given to 5 decimal places) $\langle 0.00004,0.99373\rangle$. The overlap of the propensity score values of both groups is shown in the form of a histogram in Figure 2 (blue colour shows the propensity score of the non-treated, red colour of treated individuals). 
Figure 2 | Histograms of propensity score before matching

Population Pyramid Frequency Predicted probability by intervention intervention

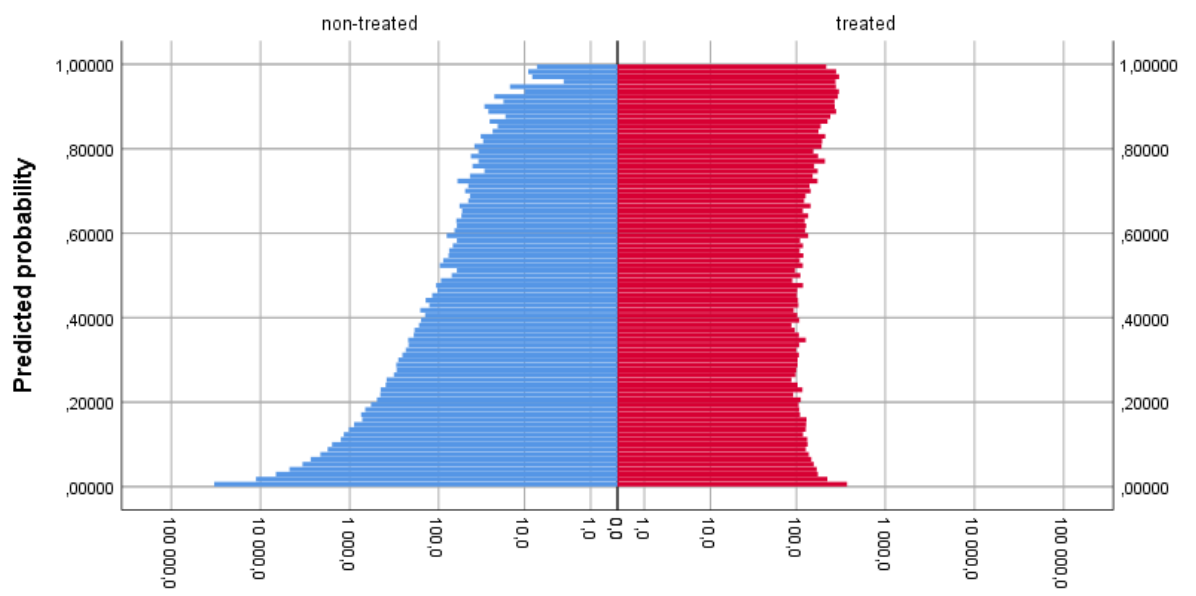

Source: own elaboration in SPSS

The predicted values of the propensity score were used for matching individuals by the calliper matching method with replacement. The balance of the generated matched samples was verified in several ways:

- Comparison of covariate characteristics in both samples (by calculation and graphical representation using a box plot). The variables have very similar characteristics, so the samples are balanced after matching.

- Comparison of the values of pseudo-R-square by re-creating the propensity score model, according to Sianesi (2004). This model have very low pseudo-R-square value (Cox \& Snell R Square $=0.076$; Nagelkerke R Square $=0.106$ ) in comparison with the model before the matching (Cox \& Snell $R$ Square $=0.31$; Nagelkerke $R$ Square $=$ 0.569).

- $\quad$ Calculating the values of normalised differences of covariates, according to Imbens \& Rubin (2015). All these are lower than 0.25 , so we consider the matching to be of good quality and the matched samples created to be sufficiently balanced.

We also verified the quality of the matching by comparing the values of the propensity score in both groups, according to Cerulli (2015) (the difference in means $=0.098, p$-value $=0.013$ ). Based on these criteria, we can say that the matching is sufficiently accurate, and the matched samples are balanced in covariate values.

After the matching, the following numbers of individuals (Table 5), also expressed as a proportion of the original sample, remains in matched samples. 
Table 5 | Numbers of individuals in the samples

\begin{tabular}{cccc}
\hline Group & Before matching & After matching & $\begin{array}{c}\text { Proportion of the sample } \\
\text { before matching in \% }\end{array}$ \\
\hline Treated & 12,953 & 11,367 & 87.76 \\
Non-treated & 83,907 & 5,748 & 6.85 \\
Sum & 96,860 & 17,115 & 17.67 \\
\hline
\end{tabular}

Source: own elaboration

Since we created a plausible counterfactual situation for treated individuals by creating a matched control sample of non-treated individuals who have as-similar-as-possible propensity scores for participation in the intervention and match characteristics, we quantify the effect of the intervention as the difference in mean values of the result variable in the groups. Table 6 shows the characteristics of the model for estimating the propensity score along with the difference in mean propensity score values in the treated and non-treated groups and its significance test.

Table 6 | Evaluation by a method of propensity score matching and its characteristics

\begin{tabular}{lcc}
\hline \multicolumn{3}{l}{ Propensity score matching method } \\
\hline Characteristic & Value & p-value \\
\hline ANOVA test of model significance & 267.35 & 0.000 \\
Nagelkerke R square & 0.31 & \\
Cox \& Snell R Square & 0.569 & \\
Net effect of the Graduate practice & $\mathbf{6 7 . 8 5}$ & $\mathbf{0 . 0 0 0}$ \\
\hline
\end{tabular}

Source: own elaboration

A comparison of individuals' results during the impact period shows that a significant positive effect of the intervention was achieved in the treated groups. Those individuals who took part in the Graduate practice stayed in employment on average almost 68 days longer than the control individuals in their employment.

\section{Discussion}

Evaluations obtained by the previous three methods shown that the Graduate practice has significant positive results on the employability of young jobseekers. We obtained results that are similar to the evaluations carried out in Slovakia so far. As we already mentioned, only a few authors have so far addressed the issue of applying a counterfactual approach to the impact evaluation of active labour market policy interventions in Slovakia. Among the studies aimed at, among others, also the Graduate practice measure, Harvan (2011) applied a counterfactual approach using a control group of non-participating individuals. The evaluation showed that the participants in the Graduate practice achieved on average better results (3 $\%$ higher employability) than those who did not participate. Compared to this, our study uses data on individuals, which we consider to be more accurate to create the best possible counterfactual situation, leading to more accurate results of the evaluation of the effects of the intervention. The study of Barosova \& Keselova (2012) shows that the analysed measures have some impacts, but using aggregated data, it is not possible to say conclusions about their effectiveness or inefficiency. In contrast to this study, we consider our study to be more accurate due to the use of micro-data on individuals and also due to the application of 
a counterfactual approach to evaluation. This analysis resulted in the main recommendation to create a sufficiently high quality and accessible database that could be used to carry out a rigorous impact assessment of the programs in Slovakia. The pilot study of Borik \& Caban (2013) shows that the Graduate Practice is a useful intervention, increasing the employment of treated participants by approximately two months on average, and job sustainability was largely short-term. The authors did not use the matching of individuals in this evaluation. The interventions were evaluated only by a simple comparison of the values of the result variables in the whole samples of treated and control individuals. However, this study should rather be considered as a pilot evaluation, which preceded the next larger-scale study by Borik, Durica, Molnarova, \& Svabova (2015) and served to acquaint the authors of the study with the data that Slovak institutions can provide to analysts. Given the evaluation of the entire samples without matching of treated and non-treated individuals, the results of this study cannot be considered authoritative. The mentioned consequent study of Borik et al. (2015) uses a counterfactual approach to assess the effects of the Graduate Practice. This evaluation focuses on older programming periods (2007-2012). In addition to those mentioned, several other evaluations have been carried out in Slovakia, focusing on interventions for the unemployed jobseekers, but these do not use a counterfactual approach and are not focused on the intervention we are discussing in this study.

To summarise, the authors found significant positive results of the Graduate Practice on the employability of its participants, on the sustainability of the jobs obtained (especially in the short and medium-term) and also on the average monthly wage earned during the impact period.

In this study, we focused on assessing the effects of this intervention on the employability of young jobseekers. We consider the regression adjustment to be the starting point for comparison with other methods. Most authors do not consider this method to be very accurate as it only takes into account the values of observable variables - individual characteristics, unobservable variables affecting participation in the intervention, and the results of the individual are not taken into account. Therefore, the results obtained by this method tend to be further refined using more sophisticated approaches to evaluation. This case is, for example, the method of the instrumental variable. In our case, however, it turned out that by evaluating the intervention with this approach, we got significantly different results from the other methods. This result confirms the assertion of KPMG (2015), where the authors emphasise that the estimated average effect of the treatment is dependent on the instrumental variable used, as different instruments may induce different variations in the intervention variable. It is therefore clear that using another instrument would give different results. We highly recommend combining this method with other methods, especially those using matching of individuals from the treated and non-treated groups. We consider the application of a combined evaluation method as a possible further direction of this study. We will also try to obtain sufficient data for the application of evaluation using different (respectively another) instrumental variable. It would also be possible to focus in the evaluation on finding out the effects of the Graduate Practice on selected segments of participants, for example, according to their gender, level of education or region of permanent residence. 


\section{Conclusion}

In this study, we focused on the evaluation of the effects of the intervention Graduate practice, which is one of the measures of active labour market policy in Slovakia. This intervention is aimed at young jobseekers under the age of 26 and aims to help young graduates acquire the first work experience, skills, and habits that can be valuable to future potential employers. The desired effect of the intervention is the employment of young jobseekers, which also reduces the cost of unemployment from the state budget. The evaluation of the net effects was carried out by three counterfactual methods: the regression adjustment method, the instrument variables method and the propensity score matching method.

In all three cases, the evaluation showed significant positive effects of the Graduate practice on the employability of young jobseekers, which increased by at least two months from the two-year impact period of the intervention. We consider the results obtained by the method of propensity score matching to be the most accurate in this evaluation because in this method matching of participants and non-participants of the intervention was realised, and the balance of the samples was confirmed by several methods, so we can say that the results of this evaluation are sufficiently accurate. This method quantified the positive impact of the intervention by increasing the employment rate of young people by almost 68 days. This result indicates the desired positive effect of the intervention.

However, it is also necessary to acknowledge the weakness of this method and thus of this study, namely the impact of self-selection of individuals on the intervention that is voluntary in Slovakia. Participants' motivation to participate in the intervention also affects their outcome variables after the intervention. Positive results of graduates may, therefore, be incorrectly attributed to the intervention, and its impact is therefore overestimated. In further analysis of the effects of the Graduate practice, we propose combining the method of propensity score matching with other methods, such as the instrumental variables method. This ensures all the necessary aspects in terms of the accuracy because of matched samples and also taking into account the effects of self-selection and selection-bias effect.

The results of this assessment, but also other active labour market policy interventions, are very valuable for the preparation of future programs for the unemployed, which will bring the desired effect. Such results should be widely used in evidence-based policy-making, the implementation of which is largely maintained by the European Union.

\section{Acknowledgement}

The authors are thankful to the Internal Grant Agency of University No. 3/PEDAS/2019: "Modelling the applicability of intervened jobseekers in the Slovak labour market: Counterfactual Approach" for financial support to carry out this research.

\section{References}

Agocs, P., \& Agocs, S. (1994). Youth in post-communist Hungary. Society, 31(3), 76-81. https://doi.org/10.1007/BF02693235

Angrist, J. D., \& Pischke, J.-S. (2009). Mostly Harmless Econometrics: An Empiricist's Companion (1 edition). Princeton University Press. 
Arco-Tirado, J. L., Fernández-Martín, F., Ramos-García, A. M., Littvay, L., Villoria, J., \& Naranjo, J. A. (2018). A counterfactual impact evaluation of a bilingual program on students' grade point average at a spanish university. Evaluation and Program Planning, 68, 81-89. https://doi.org/10.1016/j.evalprogplan.2018.02.013

Barcakova, M., \& Janas, K. (2019). Youth Unemployment in Slovakia and in Slovenia. Izzivi Prihodnosti / Challenges of the Future, 4(2), 98-105.

Barosova, M., \& Keselova, D. (2012). Application of active labor market measures in the context of European Union application practice(Final report VU n. 2159). Ministry of Labor, Social Affairs and Family of the Slovak Republic, Labor Market Policy Department. https://www.ceit.sk/IVPR/images/IVPR/vyskum/2012/Barosova/2159_kolektiv.pdf

Bell, D. N. F., \& Blanchflower, D. G. (2011). Young people and the Great Recession. Oxford Review of Economic Policy, 27(2), 241-267. https://doi.org/10.1093/oxrep/grr011

Borik, V., \& Caban, M. (2013). Pilot impact evaluation of selected active labor market policy measures [Pilotné hodnotenie dopadov vybraných opatrení aktívnej politiky trhu práce]. The Ministry of Labour, Social Affairs and Family of the Slovak Republic.

Borik, V., Durica, M., Molnarova, M., \& Svabova, L. (2015). The net effects of graduate work experience and the promotion of self-employment: Technical report. The Ministry of Labour, Social Affairs and Family of the Slovak Republic.

Burda, M. C., \& Lubyova, M. (1995). The Impact of Active Labour Market Policies: A Closer Look at the Czech and Slovak Republics. Centre for Economic Policy Research. https://cepr.org/active/publications/discussion_papers/dp.php?dpno=1102\#

Caliendo, M., Künn, S., \& Mahlstedt, R. (2017). The return to labor market mobility: An evaluation of relocation assistance for the unemployed. Journal of Public Economics, 148, 136-151. https://doi.org/10.1016/j.jpubeco.2017.02.008

Caliendo, M., \& Schmidl, R. (2016). Youth unemployment and active labor market policies in Europe. IZA Journal of Labor Policy, 5(1), 1. https://doi.org/10.1186/s40173-016-0057-x

Cappellini, E., Maitino, M., Patacchini, V., \& Sciclone, N. (2019). Are traineeships stepping-stones for youth working careers in Italy? International Journal of Manpower, 40(8), 1389-1410. https://doi.org/10.1108/IJM-03-2018-0099

Cefalo, R., Scandurra, R., \& Kazepov, Y. (2020). Youth Labor Market Integration in European Regions. Sustainability, 12(9), 3813. https://doi.org/10.3390/su12093813

Cerulli, G. (2015). Econometric Evaluation of Socio-Economic Programs: Theory and Applications. Springer-Verlag. https://doi.org/10.1007/978-3-662-46405-2

CRIE. (2014). Handout for the training workshop on counterfactual impact evaluation.

Donato, L., Migliore, M. C., \& Poy, S. (2018). Employment Effects of Vocational Training: An Evaluation Using Propensity Score Matching. Politica Economica, 3, 273-296.

Dunsch, S. (2016). Okun's Law and Youth Unemployment in Germany and Poland. International Journal of Management and Economics, 49(1), 34-57. https://doi.org/10.1515/ijme-2016-0003

Dvoulety, O. (2017). Does the Self-employment Policy Reduce Unemployment and Increase Employment? Empirical Evidence from the Czech Regions. Central European Journal of Public Policy, 11(2), 11-22. https://doi.org/10.1515/cejpp-2016-0032

Dvoulety, O., \& Lukes, M. (2016). Review of Empirical Studies on Self-Employment out of Unemployment: Do Self-Employment Policies Make a Positive Impact? Nternational Review of Entrepreneurship, 14(3), 361-376. 
Elia, L., Santangelo, G., \& Schnepf, S. V. (2016). Synthesis report on the call 'Pilot projects to carry out ESF related counterfactual impact evaluations'. Publications Office of the European Union. http://op.europa.eu/en/publication-detail/-/publication/3d8a3354-084d-11e6-b71301aa75ed71a1/language-en

European Parliament. (2020, 15th July). Covid-19: How the EU fights youth unemployment / News / European

Parliament. https://www.europarl.europa.eu/news/en/headlines/society/20200709STO83004/covid-19how-the-eu-fights-youth-unemployment

Eurostat. (2020). Young people aged 15-24 neither in employment nor in education and training (NEET), by sex-Quarterly data. http://appsso.eurostat.ec.europa.eu/nui/show.do?lang=en\&dataset=lfsi_neet_q

Frondel, M., \& Schmidt, C. M. (2005). Evaluating environmental programs: The perspective of modern evaluation research. Ecological Economics, 55(4), 515-526. https://doi.org/10.1016/j.ecolecon.2004.12.013

Golias, P. (2014). How to decrease unemployment in Slovakia. Joint seminar of the European Commission Representation in Slovakia and the institute INEKO "How to reduce unemployment in Slovakia," Bratislava, Slovakia.

Grandtnerova, L. (2014). Promoting employment for young people [Podpora zamestnanosti pre mladých ludí]. Ministry of Labor, Social Affairs and Family of the Slovak Republic, Labor Section, Institute for Work and Ramily Research. https://www.ceit.sk/IVPR/images/IVPR/NSZ/nsz_10.pdf

Gregova, E., \& Dengov, V. (2015). The Practical Economic Policy in Transition Economies of V4 Countries at the Present Stage of Globalization. Globalisation and Its Socio-Economic Consequences: 15th International Scientific Conference: Proceedings, 150-156. https://pureportal.spbu.ru/en/publications/the-practical-economic-policy-in-transitioneconomiesof-v4-countr

Gripaios, P., Bishop, P., Hart, T., \& McVittie, E. (2008). Analysing the Impact of Objective 1 Funding in Europe: A Review: Environment and Planning C: Government and Policy, 26(3), 499-524. https://doi.org/10.1068/c64m

Harvan, P. (2011). Evaluation of efficiency and effectiveness of active labor market policy expenditures in Slovakia [Hodnotenie efektívnosti a účinnosti výdavkov na aktívne politiky trhu práce na Slovensku]. Ministry of Finance of Slovak Republic.

Imbens, G. W., \& Rubin, D. B. (2015). Causal Inference for Statistics, Social, and Biomedical Sciences: An Introduction. Cambridge University Press. https://doi.org/10.1017/CBO9781139025751

Janicko, P. (2012). Youth Employment in the Czech Republic. Friedrich-Ebert-Stiftung. https://library.fes.de/pdf-files/id/09471.pdf

Karasova, K. (2013). Active labor market measures and their impact on the dynamics of unemployment in the Slovak Republic [Dissertation thesis]. University of Economics in Bratislava, Faculty of Economic Informatics, Department of Statistics.

Knox, V., Hill, C. J., \& Berlin, G. (2018). Can Evidence-Based Policy Ameliorate the Nation's Social Problems? The ANNALS of the American Academy of Political and Social Science, 678(1), 166-179. https://doi.org/10.1177/0002716218769844

Kostolna, Z. (2010). Unemployment of school leavers and approaches to its solution in EU member states during the global economic crisis [Nezamestnanost' absolventov škôl a prístupy $k$ jej riešeniu v členských štátoch EU v období globálnej ekonomickej krízy] (Final Report Vú n. 
2146). Ministry of Labor, Social Affairs and Family of the Slovak Republic, Labor Section, Institute for Work and Family Research. https://www.ceit.sk/IVPR/images/IVPR/vyskum/2010/Kostolna/VU_2146_Kostolna.pdf

Koszela, A. (2020). The influence of staff turnover on work motivation and job performance of employees in IT sector - the results of empirical research. Forum Scientiae Oeconomia, 8(1), 29-48. https://doi.org/10.23762/FSO_VOL8_NO1_3

KPMG. (2015a). Analysis of youth unemployment in the Slovak Republic [Analýza nezamestnanosti mladých ludí $v$ SR] (p. 88) [Final report]. Slovak Government Office. file://C:/Users/lucix/Downloads/Anal\%C3\%BDza\%20nezamestnanosti\%20mlad\%C3\%BDch \%20\%C4\%BEud\%C3\%AD\%20v\%20SR\%20\%20Z\%C3\%A1vere\%C4\%8Dn\%C3\%A1\%20spr\%C3\%A1va.pdf

KPMG. (2015b). Counterfactual Impact Evaluation https://www.partnerskadohoda.gov.sk/data/files/77_epublikaciaeu.pdf

Kurekova Mytna, L., Salner, A., \& Farenzenova, M. (2013). Implementácia aktivačných prác na Slovensku: Hodnotenie a odporúčania pre verejnú politiku, Zhrnutie záverečnej správy. Slovak Governance Institute Bratislava. http://staryweb.governance.sk/assets/files/publikacie/AKTIVACNE_PRACE_SGI_SK-_ZHRNUTIE.pdf

Lelkes, G., Kmet, P., Ondrus, B., Pribelsky, V., \& Vaclavova, M. (2019). NEET in Slovakia-With whom and how [NEET $v$ SR - s kým a ako] (National Project Support for the Quality of Social Dialogue, p. 80). https://www.ia.gov.sk/data/files/np_PKSD/Analyzy/Stat/NEET_SR__s_kym_a_ako.pdf

Lenihan, H., \& Hart, M. (2016). The Use of Counterfactual Scenarios as a Means to Assess Policy Deadweight: An Irish Case Study: Environment and Planning C: Government and Policy, 22(6), 817-839. https://doi.org/10.1068/c0413

Lubyova, M. (1997). Aktívna politika trhu práce v Slovenskej republike. Centrum pre hospodársky rozvoj, $s$ podporou Ford Foundation a zastúpenia nadácie F. Eberta.

Maguire, S., Cockx, B., Dolado, J. J., Felgueroso, F., Jansen, M., Styczyńska, I., Kelly, E., McGuinness, S., Eichhorst, W., Hinte, H., \& Rinne, U. (2013). Youth unemployment. Intereconomics, 48(4), 196-235. https://doi.org/10.1007/s10272-013-0464-9

Marginean, S. (2014). Youth Unemployment in Romania: Post-crisis Challenges. Procedia Economics and Finance, 16, 613-620. https://doi.org/10.1016/S2212-5671(14)00848-X

Mikiashvili, N., \& Lobzhanidze, N. (2017). Green innovations and economic policy in small economies. Forum Scientiae Oeconomia, 5(2), 29-40. https://doi.org/10.23762/fso_vol5no2_17_3

Mueller, C. E., \& Gaus, H. (2015). Assessing the performance of the "Counterfactual as Self-Estimated by Program Participants": Results From a Randomized Controlled Trial. American Journal of Evaluation, 36(1), 7-24. https://doi.org/10.1177/1098214014538487

Noelke, C., \& Horn, D. (2014). Social Transformation and the Transition from Vocational Education to Work in Hungary: A Differences-in-differences Approach. European Sociological Review, 30(4), 431-443. https://doi.org/10.1093/esr/jcu048

OECD. (2010). OECD Employment Outlook 2010: Moving beyond the Jobs Crisis. OECD. https://doi.org/10.1787/empl_outlook-2010-en

OECD. (2020a). Unemployment_Unemployment rate by age group-OECD Data. TheOECD. http://data.oecd.org/unemp/unemployment-rate-by-age-group.htm 
OECD. (2020b). Unemployment_Youth unemployment rate-OECD Data. TheOECD. http://data.oecd.org/unemp/youth-unemployment-rate.htm

Patache, L. (2015). TRENDS IN YOUTH EMPLOYMENT: ROMANIA CASE OF STUDY. Ecoforum Journal, 4(SI 1), 147-152.

Pelucha, M., Kveton, V., \& Potluka, O. (2019). Using mixed method approach in measuring effects of training in firms: Case study of the European Social Fund support. Evaluation and Program Planning, 73, 146-155. https://doi.org/10.1016/j.evalprogplan.2018.12.008

Polakowski, M. (2012). Youth Unemployment in Poland. Friedrich-Ebert-Stiftung. http://library.fes.de/pdffiles/id/09477.pdf

Popescu, M. E., \& Roman, M. (2018). Vocational training and employability: Evaluation evidence from Romania. Evaluation and Program Planning, 67(C), 38-46.

Potluka, O., Bruha, J., Spacek, M., \& Vrbova, L. (2016). Counterfactual Impact Evaluation on EU Cohesion Policy Interventions in Training in Companies. Ekonomicky Casopis, 64(6), 575595.

Quintini, G., Martin, J. P., \& Martin, S. (2007). The Changing Nature of the School-to-Work Transition Process in OECD Countries. SSRN Electronic Journal, IZA DP No. 2582. https://doi.org/10.2139/ssrn.1884070

Ragazzi, E. (2014). Effectiveness Evaluation of Training Programmes for Disadvantaged Targets. Procedia - Social and Behavioral Sciences, 141, 1239-1243. https://doi.org/10.1016/j.sbspro.2014.05.213

Research Institute of Labor and Social Affairs of the Czech Republic. (2003). Problems of labor market and employment policy [Problémy trhu práce a politiky zaměstnanosti] [Summary report from a research study carried out under the "Modern Society" program]. Ministry of Labor and Social Affairs of the Czech Republic. https://www.mpsv.cz/documents/20142/848077/zprava.pdf/1d796cfb-d654-4d97-0226d410d44723a5

Sianesi, B. (2004). An Evaluation of the Swedish System of Active Labor Market Programs in the 1990s. The Review of Economics and Statistics, 86(1), 133-155. https://doi.org/10.1162/003465304323023723

Stefanik, M. (2014). Estimating treatment effects of a training programme in Slovakia using propensity score matching. Ekonomický Časopis (Journal of Economics), 62(6), 631-645.

Stefanik, M., Karasova, K., \& Studena, I. (2020). Can supporting workplace insertions of unemployed recent graduates improve their long-term employability? Empirica, 47(2), 245-265. https://doi.org/10.1007/s10663-018-9413-y

Stefanik, M., Lubyova, M., Dovalova, G., \& Karasova, K. (2014a). Analysis of the effects of active labor market policy measures. The Ministry of Labour, Social Affairs and Family of the Slovak Republic.

https://www.ia.gov.sk/data/files/np_csd_I/KOZ/Analyza_ucinkov_nastrojov_aktivnej_politiky_t rhu_prace_finalna_verzia.pdf

Stefanik, M., Lubyova, M., Dovalova, G., \& Karasova, K. (2014b). Analysis of the effects of active labor market policy measures [Analýza účinkov nástrojov aktívnej politiky trhu práce]. The Ministry of Labour, Social Affairs and Family of the Slovak Republic. https://www.ia.gov.sk/data/files/np_csd_l/KOZ/Analyza_ucinkov_nastrojov_aktivnej_politiky_t rhu_prace_finalna_verzia.pdf 
Styczynska, I. (2020). In-depth analysis on "Social impact investment: Best practices and recommendations for the next generation." http://case-research.eu/en/in-depth-analysis-onsocial-impact-investment-best-practices-and-recommendations-for-the-next-generation101465

Svabova, L., \& Durica, M. (2018). Who were the jobseekers treated by the graduate practice intervention? A closer view on the beneficiaries of the intervention. Proceedings of the Faculty of Economics of Matej Bel University in Banska Bystrica. Volume I., 614-624.

Trivellato, U. (2011). Fifteen years of labour market regulations and policies in Italy: What have we learned from their evaluation? Statistica, 71(2), 167-187. https://doi.org/10.6092/issn.1973$2201 / 3610$

Walther, A., Zentner, M., Cicognani, E., Hansen, B. J., Kühn, R., Szelenyi, Z., \& Williamson, H. (2008). Youth policy in Hungary: Conclusions of the Council of Europe international review team. Council of Europe Publ.

White, H., \& Sabarwal, S. (2014). Quasi-Experimental Design and Methods: Methodological Briefs Impact Evaluation No. 8. https://econpapers.repec.org/paper/ucfmetbri/innpub753.htm

The research paper passed the review process. | Received: July 2, 2020; Revised: November 2, 2020; Accepted: November 9, 2020; Pre-published online: May 25, 2021; Published in the regular issue: September 20, 2021. 


\begin{tabular}{|c|c|c|c|c|c|c|}
\hline \multicolumn{7}{|c|}{ Parameter estimates } \\
\hline Dependent variable: & placed in & the labol & Ir market & & & \\
\hline \multirow{2}{*}{ Parameter } & \multirow{2}{*}{ B } & \multirow{2}{*}{$\begin{array}{l}\text { Std. } \\
\text { Error }\end{array}$} & \multirow{2}{*}{$t$} & \multirow{2}{*}{ Sig. } & \multicolumn{2}{|c|}{$\begin{array}{c}\text { 95\% Confidence } \\
\text { Interval }\end{array}$} \\
\hline & & & & & $\begin{array}{l}\text { Lower } \\
\text { Bound }\end{array}$ & $\begin{array}{l}\text { Upper } \\
\text { Bound }\end{array}$ \\
\hline Intercept & -269.083 & 35.281 & -7.627 & 0.000 & -338.233 & -199.933 \\
\hline [intervention=0] & -77.784 & 1.197 & -64.981 & 0.000 & -80.130 & -75.438 \\
\hline [intervention=1] & $0^{\mathrm{a}}$ & & & & & \\
\hline [gender $=0$ ] & 24.273 & 20.838 & 1.165 & 0.244 & -16.568 & 65.115 \\
\hline [gender $=1$ ] & 29.821 & 20.837 & 1.431 & 0.152 & -11.020 & 70.662 \\
\hline [gender=2] & $0^{\mathrm{a}}$ & & & & & \\
\hline [marital_status $=1$ ] & 37.413 & 4.490 & 8.333 & 0.000 & 28.614 & 46.213 \\
\hline [marital_status=2] & 44.940 & 4.715 & 9.532 & 0.000 & 35.700 & 54.180 \\
\hline [marital_status=3] & 52.867 & 8.893 & 5.945 & 0.000 & 35.436 & 70.297 \\
\hline [marital_status=4] & 24.871 & 39.599 & 0.628 & 0.530 & -52.742 & 102.484 \\
\hline [marital_status $=5$ ] & $0^{\mathrm{a}}$ & & & & & \\
\hline [level_of_education=1] & 10.520 & 7.628 & 1.379 & 0.168 & -4.431 & 25.471 \\
\hline [level_of_education=2] & 23.429 & 6.943 & 3.374 & 0.001 & 9.821 & 37.037 \\
\hline [level_of_education=3] & 35.810 & 7.874 & 4.548 & 0.000 & 20.377 & 51.243 \\
\hline [level_of_education=4] & 41.131 & 6.738 & 6.105 & 0.000 & 27.926 & 54.337 \\
\hline [level_of_education=5] & 37.455 & 6.705 & 5.586 & 0.000 & 24.313 & 50.597 \\
\hline [level_of_education=6] & 2.951 & 7.708 & 0.383 & 0.702 & -12.156 & 18.058 \\
\hline [level_of_education=7] & 15.509 & 9.592 & 1.617 & 0.106 & -3.291 & 34.309 \\
\hline [level_of_education=8] & 16.693 & 18.704 & 0.892 & 0.372 & -19.967 & 53.353 \\
\hline [level_of_education=9] & 19.961 & 18.672 & 1.069 & 0.285 & -16.635 & 56.557 \\
\hline [level_of_education=10] & -21.967 & 39.422 & -0.557 & 0.577 & -99.233 & 55.299 \\
\hline [level_of_education=11] & $0^{a}$ & & & & & \\
\hline [disadvantage $=1]$ & -17.157 & 23.938 & -0.717 & 0.474 & -64.075 & 29.760 \\
\hline [disadvantage $=2$ ] & -34.389 & 23.933 & -1.437 & 0.151 & -81.298 & 12.520 \\
\hline [disadvantage=3] & -26.165 & 23.920 & -1.094 & 0.274 & -73.048 & 20.719 \\
\hline [disadvantage $=4$ ] & 13.926 & 35.997 & 0.387 & 0.699 & -56.627 & 84.479 \\
\hline [disadvantage $=5$ ] & -26.723 & 27.931 & -0.957 & 0.339 & -81.468 & 28.022 \\
\hline [disadvantage $=6$ ] & 12.302 & 36.686 & 0.335 & 0.737 & -59.603 & 84.207 \\
\hline [disadvantage $=7$ ] & $0^{\mathrm{a}}$ & & & & & \\
\hline [driving_licence_group1=.00] & -1.696 & 5.868 & -0.289 & 0.773 & -13.197 & 9.805 \\
\hline [driving_licence_group1=1.00] & $0^{\mathrm{a}}$ & & & & & \\
\hline [driving_licence_group2 $=.00$ ] & 14.006 & 5.876 & 2.384 & 0.017 & 2.490 & 25.522 \\
\hline [driving_licence_group2=1.00] & $0^{\mathrm{a}}$ & & & & & \\
\hline [driving_licence_group3=.00] & -23.260 & 4.888 & -4.758 & 0.000 & -32.842 & -13.679 \\
\hline [driving_licence_group3=1.00] & $0^{\mathrm{a}}$ & & & & & \\
\hline [driving_licence_group4=.00] & 4.895 & 7.339 & 0.667 & 0.505 & -9.489 & 19.280 \\
\hline [driving_licence_group4=1.00] & $0^{\mathrm{a}}$ & & & & & \\
\hline [driving_licence_group5=0] & 5.663 & 4.189 & 1.352 & 0.176 & -2.548 & 13.873 \\
\hline [driving_licence_group5=1] & $0^{\mathrm{a}}$ & & & & & \\
\hline [region_of_permanent_residence=1] & 74.420 & 9.572 & 7.775 & 0.000 & 55.659 & 93.182 \\
\hline [region_of_permanent_residence=2] & 81.493 & 9.539 & 8.543 & 0.000 & 62.796 & 100.190 \\
\hline
\end{tabular}




\begin{tabular}{|c|c|c|c|c|c|c|}
\hline \multirow[t]{3}{*}{ Dependent variable: } & \multicolumn{6}{|c|}{ placed in the labour market } \\
\hline & \multirow{2}{*}{ B } & \multirow{2}{*}{$\begin{array}{l}\text { Std. } \\
\text { Error }\end{array}$} & \multirow{2}{*}{$\mathbf{t}$} & \multirow{2}{*}{ Sig. } & \multicolumn{2}{|c|}{$\begin{array}{c}95 \% \text { Confidence } \\
\text { Interval }\end{array}$} \\
\hline & & & & & $\begin{array}{l}\text { Lower } \\
\text { Bound }\end{array}$ & $\begin{array}{l}\text { Upper } \\
\text { Bound }\end{array}$ \\
\hline [region_of_permanent_residence=3] & 78.208 & 9.535 & 8.202 & 0.000 & 59.519 & 96.896 \\
\hline [region_of_permanent_residence=4] & 71.513 & 9.523 & 7.510 & 0.000 & 52.848 & 90.177 \\
\hline [region_of_permanent_residence=5] & 70.014 & 9.517 & 7.357 & 0.000 & 51.361 & 88.667 \\
\hline [region_of_permanent_residence=6] & 61.643 & 9.519 & 6.476 & 0.000 & 42.986 & 80.300 \\
\hline [region_of_permanent_residence=7] & 59.051 & 9.507 & 6.211 & 0.000 & 40.418 & 77.685 \\
\hline [region_of_permanent_residence=8] & 66.391 & 9.511 & 6.980 & 0.000 & 47.749 & 85.032 \\
\hline [region_of_permanent_residence=99] & $0^{\mathrm{a}}$ & & & & & \\
\hline$[$ school=1] & -24.583 & 6.946 & -3.539 & 0.000 & -38.197 & -10.968 \\
\hline [school=2] & 33.154 & 9.801 & 3.383 & 0.001 & 13.944 & 52.364 \\
\hline [school=3] & 36.850 & 10.545 & 3.495 & 0.000 & 16.182 & 57.517 \\
\hline$[$ school=4] & 18.395 & 9.013 & 2.041 & 0.041 & 0.729 & 36.061 \\
\hline [school=5] & 18.505 & 8.390 & 2.206 & 0.027 & 2.061 & 34.948 \\
\hline [school=6] & 0.195 & 15.191 & 0.013 & 0.990 & -29.580 & 29.970 \\
\hline$[$ school=7] & 23.059 & 8.311 & 2.774 & 0.006 & 6.769 & 39.350 \\
\hline [school=8] & 19.376 & 24.452 & 0.792 & 0.428 & -28.549 & 67.301 \\
\hline [school=9] & 73.394 & 15.856 & 4.629 & 0.000 & 42.315 & 104.472 \\
\hline [school=10] & 16.035 & 9.323 & 1.720 & 0.085 & -2.237 & 34.308 \\
\hline [school=11] & -2.469 & 18.438 & -0.134 & 0.893 & -38.608 & 33.670 \\
\hline [school=12] & 23.560 & 12.559 & 1.876 & 0.061 & -1.056 & 48.176 \\
\hline [school=13] & 27.815 & 8.201 & 3.392 & 0.001 & 11.742 & 43.888 \\
\hline [school=14] & 20.368 & 8.230 & 2.475 & 0.013 & 4.237 & 36.500 \\
\hline [school=15] & 20.393 & 52.689 & 0.387 & 0.699 & -82.877 & 123.664 \\
\hline [school=16] & 40.887 & 43.276 & 0.945 & 0.345 & -43.933 & 125.707 \\
\hline [school=17] & -50.421 & 11.336 & -4.448 & 0.000 & -72.639 & -28.202 \\
\hline [school=18] & -76.717 & 18.586 & -4.128 & 0.000 & -113.145 & -40.288 \\
\hline [school=19] & 16.470 & 10.257 & 1.606 & 0.108 & -3.634 & 36.574 \\
\hline [school=20] & 20.985 & 8.294 & 2.530 & 0.011 & 4.728 & 37.242 \\
\hline [school=21] & 18.700 & 8.530 & 2.192 & 0.028 & 1.980 & 35.419 \\
\hline [school=22] & 0.753 & 9.392 & 0.080 & 0.936 & -17.655 & 19.162 \\
\hline [school=23] & 27.667 & 8.645 & 3.200 & 0.001 & 10.722 & 44.612 \\
\hline [school=24] & 87.238 & 60.105 & 1.451 & 0.147 & -30.568 & 205.043 \\
\hline [school=25] & 45.091 & 14.487 & 3.113 & 0.002 & 16.697 & 73.485 \\
\hline [school=26] & -33.894 & 19.525 & -1.736 & 0.083 & -72.163 & 4.375 \\
\hline [school=27] & -21.976 & 22.029 & -0.998 & 0.318 & -65.153 & 21.201 \\
\hline [school=28] & -1.731 & 19.564 & -0.089 & 0.929 & -40.078 & 36.615 \\
\hline [school=29] & -15.432 & 20.992 & -0.735 & 0.462 & -56.576 & 25.712 \\
\hline [school=30] & -1.897 & 19.585 & -0.097 & 0.923 & -40.283 & 36.489 \\
\hline [school=31] & -5.159 & 19.907 & -0.259 & 0.796 & -44.177 & 33.859 \\
\hline [school=32] & -3.022 & 21.289 & -0.142 & 0.887 & -44.747 & 38.704 \\
\hline [school=33] & -13.999 & 20.008 & -0.700 & 0.484 & -53.214 & 25.217 \\
\hline [school=34] & -2.962 & 20.181 & -0.147 & 0.883 & -42.518 & 36.593 \\
\hline [school=35] & 3.543 & 19.942 & 0.178 & 0.859 & -35.543 & 42.629 \\
\hline$[$ school=36] & 3.699 & 20.076 & 0.184 & 0.854 & -35.649 & 43.047 \\
\hline
\end{tabular}




\begin{tabular}{|c|c|c|c|c|c|c|}
\hline \multirow[t]{3}{*}{ Dependent variable: } & \multicolumn{6}{|c|}{ placed in the labour market } \\
\hline & \multirow{2}{*}{ B } & \multirow{2}{*}{$\begin{array}{l}\text { Std. } \\
\text { Error }\end{array}$} & \multirow{2}{*}{$\mathbf{t}$} & \multirow{2}{*}{ Sig. } & \multicolumn{2}{|c|}{$\begin{array}{c}\text { 95\% Confidence } \\
\text { Interval }\end{array}$} \\
\hline & & & & & $\begin{array}{l}\text { Lower } \\
\text { Bound }\end{array}$ & $\begin{array}{l}\text { Upper } \\
\text { Bound }\end{array}$ \\
\hline [school=37] & -2.657 & 22.043 & -0.121 & 0.904 & -45.860 & 40.546 \\
\hline [school=38] & -47.877 & 26.705 & -1.793 & 0.073 & -100.218 & 4.465 \\
\hline [school=39] & 17.547 & 22.995 & 0.763 & 0.445 & -27.523 & 62.616 \\
\hline [school=40] & -32.025 & 19.990 & -1.602 & 0.109 & -71.206 & 7.156 \\
\hline [school=41] & 17.016 & 8.301 & 2.050 & 0.040 & 0.745 & 33.287 \\
\hline [school=42] & $0^{\mathrm{a}}$ & & & & & \\
\hline age_at_registration & -36.235 & 0.862 & -42.056 & 0.000 & -37.924 & -34.546 \\
\hline last_evidence & -0.115 & 0.002 & -55.137 & 0.000 & -0.119 & -0.111 \\
\hline total_evidence & -0.041 & 0.004 & -9.142 & 0.000 & -0.050 & -0.032 \\
\hline age & 47.788 & 0.804 & 59.463 & 0.000 & 46.213 & 49.363 \\
\hline \multicolumn{7}{|c|}{ a. This parameter is set to zero because it is redundant. } \\
\hline
\end{tabular}

Source: own elaboration 


\begin{tabular}{|c|c|c|c|c|c|c|}
\hline \multicolumn{7}{|c|}{ Parameter estimates } \\
\hline Dependent variable: & placed in & the labo & ur market & & & \\
\hline \multirow{2}{*}{ Parameter } & \multirow{2}{*}{ B } & \multirow{2}{*}{$\begin{array}{l}\text { Std. } \\
\text { Error }\end{array}$} & \multirow{2}{*}{.1.n. } & \multirow{2}{*}{ Sig. } & \multicolumn{2}{|c|}{$\begin{array}{c}\text { 95\% Confidence } \\
\text { Interval }\end{array}$} \\
\hline & & & & & $\begin{array}{l}\text { Lower } \\
\text { Bound }\end{array}$ & $\begin{array}{l}\text { Upper } \\
\text { Bound }\end{array}$ \\
\hline Intercept & -422.068 & 35.536 & -11.877 & 0.000 & -491.718 & -352.417 \\
\hline [gender $=0$ ] & 26.993 & 20.919 & 1.290 & 0.197 & -14.008 & 67.993 \\
\hline [gender $=1$ ] & 30.689 & 20.918 & 1.467 & 0.142 & -10.311 & 71.688 \\
\hline [gender=2] & $0^{\mathrm{a}}$ & & & & & \\
\hline [marital_status=1] & 34.807 & 4.508 & 7.721 & 0.000 & 25.972 & 43.643 \\
\hline [marital_status=2] & 40.509 & 4.735 & 8.555 & 0.000 & 31.228 & 49.790 \\
\hline [marital_status=3] & 44.160 & 8.932 & 4.944 & 0.000 & 26.653 & 61.668 \\
\hline [marital_status=4] & 12.023 & 39.755 & 0.302 & 0.762 & -65.897 & 89.942 \\
\hline [marital_status $=5$ ] & $0^{\mathrm{a}}$ & & & & & \\
\hline [level_of_education=1] & 19.318 & 7.664 & 2.521 & 0.012 & 4.298 & 34.339 \\
\hline [level_of_education=2] & 28.069 & 6.972 & 4.026 & 0.000 & 14.405 & 41.733 \\
\hline [level_of_education=3] & 36.165 & 7.905 & 4.575 & 0.000 & 20.672 & 51.658 \\
\hline [level_of_education=4] & 40.389 & 6.764 & 5.971 & 0.000 & 27.132 & 53.646 \\
\hline [level_of_education=5] & 32.092 & 6.733 & 4.766 & 0.000 & 18.894 & 45.290 \\
\hline [level_of_education=6] & -3.999 & 7.741 & -0.517 & 0.605 & -19.171 & 11.173 \\
\hline [level_of_education=7] & 11.406 & 9.630 & 1.184 & 0.236 & -7.468 & 30.281 \\
\hline [level_of_education=8] & 8.356 & 18.779 & 0.445 & 0.656 & -28.450 & 45.162 \\
\hline [level_of_education=9] & -7.704 & 18.767 & -0.411 & 0.681 & -44.487 & 29.079 \\
\hline [level_of_education=10] & -47.247 & 39.584 & -1.194 & 0.233 & -124.831 & 30.337 \\
\hline [level_of_education=11] & $0^{\mathrm{a}}$ & & & & & \\
\hline [disadvantage $=1]$ & -15.545 & 24.031 & -0.647 & 0.518 & -62.645 & 31.555 \\
\hline [disadvantage $=2$ ] & -24.566 & 24.029 & -1.022 & 0.307 & -71.662 & 22.530 \\
\hline [disadvantage=3] & -24.774 & 24.013 & -1.032 & 0.302 & -71.839 & 22.292 \\
\hline [disadvantage $=4]$ & 26.475 & 36.139 & 0.733 & 0.464 & -44.357 & 97.307 \\
\hline [disadvantage $=5$ ] & -12.384 & 28.044 & -0.442 & 0.659 & -67.350 & 42.582 \\
\hline [disadvantage $=6$ ] & 27.312 & 36.832 & 0.742 & 0.458 & -44.879 & 99.503 \\
\hline [disadvantage=7] & $0^{\mathrm{a}}$ & & & & & \\
\hline [driving_licence_group1=.00] & -2.088 & 5.891 & -0.354 & 0.723 & -13.633 & 9.458 \\
\hline [driving_licence_group1=1.00] & $0^{\mathrm{a}}$ & & & & & \\
\hline [driving_licence_group2=.00] & 9.891 & 5.900 & 1.676 & 0.094 & -1.673 & 21.455 \\
\hline [driving_licence_group2 $=1.00$ ] & $0^{\mathrm{a}}$ & & & & & \\
\hline [driving_licence_group3=.00] & -22.070 & 4.908 & -4.497 & 0.000 & -31.689 & -12.451 \\
\hline [driving_licence_group3=1.00] & $0^{\mathrm{a}}$ & & & & & \\
\hline [driving_licence_group4=.00] & 6.524 & 7.368 & 0.886 & 0.376 & -7.917 & 20.965 \\
\hline [driving_licence_group4=1.00] & $0^{\mathrm{a}}$ & & & & & \\
\hline [driving_licence_group5=0] & 5.632 & 4.205 & 1.339 & 0.180 & -2.610 & 13.875 \\
\hline [driving_licence_group5=1] & $0^{\mathrm{a}}$ & & & & & \\
\hline [region_of_permanent_residence $=1$ ] & 81.686 & 9.612 & 8.498 & 0.000 & 62.845 & 100.526 \\
\hline [region_of_permanent_residence=2] & 85.582 & 9.577 & 8.936 & 0.000 & 66.811 & 104.354 \\
\hline [region_of_permanent_residence=3] & 82.983 & 9.573 & 8.668 & 0.000 & 64.219 & 101.747 \\
\hline [region_of_permanent_residence $=4$ ] & 76.428 & 9.561 & 7.994 & 0.000 & 57.689 & 95.168 \\
\hline
\end{tabular}




\begin{tabular}{|c|c|c|c|c|c|c|}
\hline \multirow[t]{3}{*}{ Dependent variable: } & \multirow[t]{3}{*}{ plac } & \multirow{3}{*}{$\begin{array}{l}\text { Std. } \\
\text { Error }\end{array}$} & \multirow[t]{3}{*}{ market } & \multirow{3}{*}{ Sig. } & & \\
\hline & & & & & \multicolumn{2}{|c|}{$\begin{array}{c}\text { 95\% Confidence } \\
\text { Interval }\end{array}$} \\
\hline & & & & & $\begin{array}{l}\text { Lower } \\
\text { Bound }\end{array}$ & $\begin{array}{l}\text { Upper } \\
\text { Bound }\end{array}$ \\
\hline [region of permanent_residence $=5$ ] & 74.467 & 9.555 & 7.793 & 0.000 & 55.739 & 93.195 \\
\hline [region_of_permanent_residence=6] & 66.437 & 9.557 & 6.951 & 0.000 & 47.705 & 85.169 \\
\hline [region_of_permanent_residence=7] & 64.158 & 9.545 & 6.721 & 0.000 & 45.450 & 82.867 \\
\hline [region_of_permanent_residence=8] & 72.452 & 9.550 & 7.587 & 0.000 & 53.734 & 91.170 \\
\hline [region_of_permanent_residence=99] & $0^{\mathrm{a}}$ & & & & & \\
\hline [school=1] & -25.684 & 6.973 & -3.683 & 0.000 & -39.351 & -12.017 \\
\hline [school=2] & 30.506 & 9.839 & 3.100 & 0.002 & 11.221 & 49.792 \\
\hline [school=3] & 25.088 & 10.593 & 2.368 & 0.018 & 4.325 & 45.850 \\
\hline$[$ school=4] & 13.333 & 9.050 & 1.473 & 0.141 & -4.404 & 31.070 \\
\hline [school=5] & 12.734 & 8.424 & 1.512 & 0.131 & -3.778 & 29.246 \\
\hline [school=6] & -0.932 & 15.250 & -0.061 & 0.951 & -30.822 & 28.959 \\
\hline$[$ school=7] & 13.762 & 8.350 & 1.648 & 0.099 & -2.603 & 30.127 \\
\hline [school=8] & 16.521 & 24.547 & 0.673 & 0.501 & -31.590 & 64.633 \\
\hline [school=9] & 61.592 & 15.923 & 3.868 & 0.000 & 30.384 & 92.801 \\
\hline [school=10] & 10.516 & 9.361 & 1.123 & 0.261 & -7.831 & 28.863 \\
\hline [school=11] & 0.339 & 18.510 & 0.018 & 0.985 & -35.941 & 36.619 \\
\hline [school=12] & 24.289 & 12.608 & 1.926 & 0.054 & -0.423 & 49.000 \\
\hline [school=13] & 24.016 & 8.234 & 2.917 & 0.004 & 7.879 & 40.154 \\
\hline [school=14] & 15.684 & 8.264 & 1.898 & 0.058 & -0.513 & 31.881 \\
\hline [school=15] & -0.794 & 52.899 & -0.015 & 0.988 & -104.475 & 102.887 \\
\hline [school=16] & 41.456 & 43.444 & 0.954 & 0.340 & -43.693 & 126.606 \\
\hline$[$ school=17] & -55.766 & 11.381 & -4.900 & 0.000 & -78.074 & -33.459 \\
\hline [school=18] & -90.171 & 18.664 & -4.831 & 0.000 & -126.752 & -53.591 \\
\hline [school=19] & 2.489 & 10.307 & 0.241 & 0.809 & -17.714 & 22.691 \\
\hline [school=20] & 15.820 & 8.328 & 1.899 & 0.058 & -0.504 & 32.143 \\
\hline [school=21] & 11.379 & 8.567 & 1.328 & 0.184 & -5.412 & 28.171 \\
\hline [school=22] & -1.783 & 9.429 & -0.189 & 0.850 & -20.263 & 16.698 \\
\hline [school=23] & 23.500 & 8.680 & 2.707 & 0.007 & 6.487 & 40.513 \\
\hline [school=24] & 81.193 & 60.339 & 1.346 & 0.178 & -37.070 & 199.457 \\
\hline [school=25] & 42.132 & 14.544 & 2.897 & 0.004 & 13.626 & 70.637 \\
\hline [school=26] & -30.943 & 19.601 & -1.579 & 0.114 & -69.361 & 7.476 \\
\hline [school=27] & -48.867 & 22.133 & -2.208 & 0.027 & -92.247 & -5.487 \\
\hline [school=28] & -14.570 & 19.645 & -0.742 & 0.458 & -53.074 & 23.935 \\
\hline [school=29] & -24.319 & 21.075 & -1.154 & 0.249 & -65.627 & 16.988 \\
\hline [school=30] & -16.326 & 19.667 & -0.830 & 0.406 & -54.873 & 22.221 \\
\hline [school=31] & -18.975 & 19.990 & -0.949 & 0.343 & -58.155 & 20.205 \\
\hline [school=32] & -23.652 & 21.382 & -1.106 & 0.269 & -65.561 & 18.257 \\
\hline [school=33] & -23.117 & 20.088 & -1.151 & 0.250 & -62.489 & 16.256 \\
\hline [school=34] & -18.945 & 20.267 & -0.935 & 0.350 & -58.668 & 20.777 \\
\hline [school=35] & -12.171 & 20.026 & -0.608 & 0.543 & -51.423 & 27.080 \\
\hline [school=36] & -13.195 & 20.161 & -0.654 & 0.513 & -52.711 & 26.322 \\
\hline [school=37] & -23.817 & 22.139 & -1.076 & 0.282 & -67.210 & 19.576 \\
\hline [school=38] & -54.849 & 26.810 & -2.046 & 0.041 & -107.396 & -2.302 \\
\hline
\end{tabular}




\begin{tabular}{cccccccc}
\hline Dependent variable: & \multicolumn{9}{c}{ placed in the labour market } \\
\hline & & & & & \multicolumn{2}{c}{$\begin{array}{c}\mathbf{9 5 \%} \text { Confidence } \\
\text { Interval }\end{array}$} \\
\hline Parameter & B & $\begin{array}{c}\text { Std. } \\
\text { Error }\end{array}$ & $\mathbf{t}$ & Sig. & $\begin{array}{c}\text { Lower } \\
\text { Bound }\end{array}$ & $\begin{array}{c}\text { Upper } \\
\text { Bound }\end{array}$ \\
\hline [school=39] & & & & & -4.157 & 42.372 \\
[school=40] & -35.351 & 20.068 & -1.762 & 0.078 & -74.685 & 3.982 \\
[school=41] & 9.627 & 8.337 & 1.155 & 0.248 & -6.715 & 25.968 \\
[school=42] & $0^{\text {a }}$ & & & & & \\
age_at_registration & -42.152 & 0.887 & -47.498 & 0.000 & -43.891 & -40.412 \\
last_evidence & -0.144 & 0.002 & -62.430 & 0.000 & -0.149 & -0.140 \\
total_evidence & -0.059 & 0.005 & -12.877 & 0.000 & -0.067 & -0.050 \\
age & 56.925 & 0.863 & 65.976 & 0.000 & 55.234 & 58.616 \\
step2 & $\mathbf{1 3 8 . 7 4 2}$ & $\mathbf{2 . 3 6 5}$ & $\mathbf{5 8 . 6 7 0}$ & $\mathbf{0 . 0 0 0}$ & $\mathbf{1 3 4 . 1 0 7}$ & $\mathbf{1 4 3 . 3 7 7}$
\end{tabular}

Source: own elaboration 


\begin{tabular}{|c|c|c|c|c|c|c|}
\hline Variable & B & SE. & Wald & df & $\begin{array}{c}\mathrm{P}- \\
\text { value }\end{array}$ & $\operatorname{Exp}(B)$ \\
\hline age_at_registration & 0.08 & 0.06 & 2.18 & 1 & 0.1398 & 1.09 \\
\hline total_evidence & 0.00 & 0.00 & 31.94 & 1 & 0.0000 & 1.00 \\
\hline last_evidence & 0.00 & 0.00 & 181.69 & 1 & 0.0000 & 1.00 \\
\hline age & -0.37 & 0.05 & 44.86 & 1 & 0.0000 & 0.69 \\
\hline Driving licence group DE & 0.03 & 1.05 & 0.00 & 1 & 0.9778 & 1.03 \\
\hline Driving licence group D & 0.06 & 0.43 & 0.02 & 1 & 0.8945 & 1.06 \\
\hline Driving licence group CE & 0.34 & 0.30 & 1.28 & 1 & 0.2583 & 1.40 \\
\hline Driving licence group C & -0.47 & 0.32 & 2.15 & 1 & 0.1427 & 0.63 \\
\hline Driving licence group B & -0.06 & 0.25 & 0.06 & 1 & 0.8045 & 0.94 \\
\hline Driving licence group $A$ & 0.11 & 0.07 & 2.69 & 1 & 0.1010 & 1.12 \\
\hline Driving licence group AM & -0.26 & 0.26 & 1.04 & 1 & 0.3072 & 0.77 \\
\hline Driving licence group $T$ & 0.32 & 0.26 & 1.53 & 1 & 0.2163 & 1.37 \\
\hline ratio of women in the district & 0.00 & 0.00 & 0.02 & 1 & 0.8770 & 1.00 \\
\hline district size & -0.13 & 0.15 & 0.71 & 1 & 0.4003 & 0.88 \\
\hline district population density & 0.00 & 0.00 & 1.55 & 1 & 0.2125 & 1.00 \\
\hline $\begin{array}{c}\text { number of municipalities in the } \\
\text { district }\end{array}$ & 0.00 & 0.00 & 0.57 & 1 & 0.4518 & 1.00 \\
\hline number of towns in the district & -0.02 & 0.02 & 0.91 & 1 & 0.3398 & 0.98 \\
\hline unemployment rate & -0.01 & 0.02 & 0.39 & 1 & 0.5310 & 0.99 \\
\hline gender=men & -0.12 & 0.04 & 10.99 & 1 & 0.0009 & 0.88 \\
\hline marital status $=$ single & 0.88 & 0.62 & 2.03 & 1 & 0.1547 & 2.42 \\
\hline marital status $=$ married & 0.96 & 0.62 & 2.38 & 1 & 0.1227 & 2.62 \\
\hline marital status=divorced & 1.53 & 0.71 & 4.63 & 1 & 0.0314 & 4.61 \\
\hline marital status=widow & 0.49 & 1.18 & 0.17 & 1 & 0.6808 & 1.63 \\
\hline level of education $=1$ & -20.94 & 41225.78 & 0.00 & 1 & 0.9996 & 0.00 \\
\hline level of education $=2$ & -20.81 & 41225.78 & 0.00 & 1 & 0.9996 & 0.00 \\
\hline level of education=3 & -0.10 & 0.58 & 0.03 & 1 & 0.8633 & 0.90 \\
\hline level of education $=4$ & 0.24 & 0.53 & 0.21 & 1 & 0.6499 & 1.27 \\
\hline level of education $=5$ & 0.75 & 0.53 & 1.99 & 1 & 0.1580 & 2.11 \\
\hline level of education $=6$ & 0.80 & 0.58 & 1.94 & 1 & 0.1632 & 2.23 \\
\hline level of education $=7$ & 0.83 & 0.65 & 1.62 & 1 & 0.2037 & 2.28 \\
\hline level of education $=8$ & 0.81 & 0.67 & 1.44 & 1 & 0.2296 & 2.25 \\
\hline level of education $=9$ & 1.73 & 0.67 & 6.58 & 1 & 0.0103 & 5.62 \\
\hline level of education $=10$ & 0.97 & 1.24 & 0.61 & 1 & 0.4366 & 2.63 \\
\hline disadvantage $=$ none & -0.05 & 0.76 & 0.00 & 1 & 0.9497 & 0.95 \\
\hline disadvantage=school-leaver & -0.47 & 0.76 & 0.38 & 1 & 0.5380 & 0.63 \\
\hline $\begin{array}{c}\text { disadvantage=long term } \\
\text { unemployed }\end{array}$ & 0.00 & 0.76 & 0.00 & 1 & 0.9992 & 1.00 \\
\hline disadvantage=low education & -0.01 & 1.83 & 0.00 & 1 & 0.9962 & 0.99 \\
\hline disadvantage $=$ no regularly paid job & -0.18 & 1.06 & 0.03 & 1 & 0.8677 & 0.84 \\
\hline permanent residence $=\mathrm{BA}$ & -0.05 & 0.19 & 0.06 & 1 & 0.7993 & 0.95 \\
\hline permanent residence $=\mathrm{TT}$ & 0.01 & 0.10 & 0.02 & 1 & 0.8974 & 1.01 \\
\hline school=1 & -19.84 & 41225.78 & 0.00 & 1 & 0.9996 & 0.00 \\
\hline school=2 & -19.79 & 41225.78 & 0.00 & 1 & 0.9996 & 0.00 \\
\hline school $=3$ & -19.12 & 41225.78 & 0.00 & 1 & 0.9996 & 0.00 \\
\hline
\end{tabular}




\begin{tabular}{|c|c|c|c|c|c|c|}
\hline Variable & B & SE. & Wald & df & $\begin{array}{c}\text { P- } \\
\text { value }\end{array}$ & $\operatorname{Exp}(B)$ \\
\hline school=4 & -19.67 & 41225.78 & 0.00 & 1 & 0.9996 & 0.00 \\
\hline school $=5$ & -19.68 & 41225.78 & 0.00 & 1 & 0.9996 & 0.00 \\
\hline school= 6 & -20.66 & 41225.78 & 0.00 & 1 & 0.9996 & 0.00 \\
\hline school=7 & -19.51 & 41225.78 & 0.00 & 1 & 0.9996 & 0.00 \\
\hline school=8 & 0.90 & 47244.20 & 0.00 & 1 & 10.000 & 2.45 \\
\hline school=9 & -19.20 & 41225.78 & 0.00 & 1 & 0.9996 & 0.00 \\
\hline school=10 & -19.77 & 41225.78 & 0.00 & 1 & 0.9996 & 0.00 \\
\hline school=11 & 1.45 & 57576.38 & 0.00 & 1 & 10.000 & 4.26 \\
\hline school=12 & 0.88 & 57576.38 & 0.00 & 1 & 10.000 & 2.41 \\
\hline school=13 & -19.75 & 41225.78 & 0.00 & 1 & 0.9996 & 0.00 \\
\hline school=14 & -19.66 & 41225.78 & 0.00 & 1 & 0.9996 & 0.00 \\
\hline school=15 & -19.67 & 41225.78 & 0.00 & 1 & 0.9996 & 0.00 \\
\hline school=16 & -18.87 & 41225.78 & 0.00 & 1 & 0.9996 & 0.00 \\
\hline [school=17] & -19.60 & 41225.78 & 0.00 & 1 & 0.9996 & 0.00 \\
\hline [school=18] & -19.69 & 41225.78 & 0.00 & 1 & 0.9996 & 0.00 \\
\hline [school=19] & -19.75 & 41225.78 & 0.00 & 1 & 0.9996 & 0.00 \\
\hline [school=20] & -19.60 & 41225.78 & 0.00 & 1 & 0.9996 & 0.00 \\
\hline [school=21] & -19.81 & 41225.78 & 0.00 & 1 & 0.9996 & 0.00 \\
\hline [school=22] & -19.65 & 41225.78 & 0.00 & 1 & 0.9996 & 0.00 \\
\hline [school=23] & -19.75 & 41225.78 & 0.00 & 1 & 0.9996 & 0.00 \\
\hline [school=24] & -17.99 & 41225.78 & 0.00 & 1 & 0.9997 & 0.00 \\
\hline [school=25] & -19.26 & 41225.78 & 0.00 & 1 & 0.9996 & 0.00 \\
\hline [school=26] & -19.23 & 41225.78 & 0.00 & 1 & 0.9996 & 0.00 \\
\hline [school=27] & -19.28 & 41225.78 & 0.00 & 1 & 0.9996 & 0.00 \\
\hline [school=28] & -19.23 & 41225.78 & 0.00 & 1 & 0.9996 & 0.00 \\
\hline [school=29] & -18.96 & 41225.78 & 0.00 & 1 & 0.9996 & 0.00 \\
\hline [school=30] & -19.37 & 41225.78 & 0.00 & 1 & 0.9996 & 0.00 \\
\hline [school=31] & -19.23 & 41225.78 & 0.00 & 1 & 0.9996 & 0.00 \\
\hline [school=32] & -18.91 & 41225.78 & 0.00 & 1 & 0.9996 & 0.00 \\
\hline [school=33] & -19.13 & 41225.78 & 0.00 & 1 & 0.9996 & 0.00 \\
\hline [school=34] & -19.06 & 41225.78 & 0.00 & 1 & 0.9996 & 0.00 \\
\hline [school=35] & -19.26 & 41225.78 & 0.00 & 1 & 0.9996 & 0.00 \\
\hline [school=36] & -18.78 & 41225.78 & 0.00 & 1 & 0.9996 & 0.00 \\
\hline [school=37] & -19.56 & 41225.78 & 0.00 & 1 & 0.9996 & 0.00 \\
\hline [school=38] & -19.56 & 41225.78 & 0.00 & 1 & 0.9996 & 0.00 \\
\hline Intercept & 30.84 & 41225.78 & 0.00 & 1 & 0.9994 & 24762902823603.80 \\
\hline
\end{tabular}

Source: own elaboration 